\title{
sciendo
}

CIVIL AND ENVIRONMENTAL ENGINEERING REPORTS

E-ISSN 2450-8594

CEER 2021; 31 (2): 0218-0254

DOI: $10.2478 /$ ceer-2021-0027

Original Research Article

\section{THE EFFECTS OF DELAYS IN ALGERIAN CONSTRUCTION PROJECTS: AN EMPIRICAL STUDY}

\author{
Roumeissa SALHI ${ }^{1}$, Karima MESSAOUDI \\ Department of Civil Engineering, LMGHU Laboratory, University 20 aout 1955-Skikda, \\ Algeria
}

\begin{abstract}
This paper examines the effects of delays in the Algerian construction industry in order to identify the various critical aspects of the causes for improving the economy in the construction sector. A questionnaire survey was conducted to assess the perceptions of all players in the construction industry, which led to the identification of the most significant impacts of delays. The results show that ten main effects of delays in the construction sector are at the origin of many constraints that have a negative impact on the economy of the country. Further, the factor analysis technique was performed to categorize the identified effects into main groups, and it yielded 5 groups (factors). As an important contribution, the relationship between these groups was tested using the SMART-PLS, and a structural model has been developed. Also, a comparative study with other previous works on the most critical effect of delays in construction projects has been conducted and the results show that the main effects of delays in the construction industry are at the root of many constraints in reaching and achieving the objectives.
\end{abstract}

Keywords: construction management, construction delay, effects of delay, time control, Algeria, SMART-PLS

\footnotetext{
${ }^{1}$ Corresponding author: Department of Civil Engineering, LMGHU Laboratory, University 20 Août 1955, BP. 26, El-Hadaiek Street, 21 000, Skikda, Algeria.meissa.constantine@gmail.com, $+213790866382$
} 


\section{INTRODUCTION}

The construction industry is one of the major sectors that contribute tangibly to the economic growth of countries [11, 42,4]. Its importance is attributed to its high linkage with the other economic sectors [4]; since it allows creating the necessary infrastructure of transportation (roads, airports, ports, highways...etc) which play a pivotal role in economic activities (trade, exchange, importation, exportation). Moreover, it provides the required infrastructure for the other economic sectors (hospitals, schools, administrative buildings... etc), generates employment and wealth $[9,32,43]$, and it constitutes an efficient way to reduce poverty and improve life quality $[12,40]$.

Despite the positive impact of the construction projects on achieving the objectives of social and economic development of countries, it is always followed by different challenges among those its frequent delay. Delay is one of the most recorded and serious issues in construction projects worldwide, and it has multiple undesirable effects on projects and thereby influences the entire economy of the country. For the last two decades, extensive research on time delay has been carried out over the world. The majority of these studies are focusing on causative factors. In contrast, only a few studies are consecrated to the effects of delay while other studies are devoted to discussing both causes and effects of delay simultaneously. In 2002, Aibinu and Jagboro[3] carried out a study for identifying and evaluating the effects of delay in the Nigerian construction project, Aibinu and Jagboro[3] emphasized that time and cost overruns, litigation, arbitration, and total abandonment were the main effects of delay in the Nigerian construction project. Sambasivan and Soon [39] conducted a questionnaire survey to determine the delay factors and their effects on construction projects in Malaysia. The findings show that poor site management, improper planning, and lack of experience were the three prominent factors of delay, while the most significant effects were time overrun cost overrun, disputes, arbitration, litigation, and total abandonment. Further, an empirical relationship had been established between causes and effects. Similarly, Abdullah[1] developed a questionnaire survey to determine the main causes and effects of delay in large MARA (Majlis Amanah Rakyat) construction projects in Malaysia, and they found similar results to the findings of Sambasivan and Soon [39]. Kikwasi [24] designed a descriptive study to assess the causes and effects of delay in Tanzania. The relative importance index (RII) was adopted in ranking causes and effects. The findings show that the highly ranked causes were design change, and problems of communication, while, the most significant effects were: times and cost overruns, negative social impact, disputes, and idling resources, Owalabi et al. [35] evaluated 15 causes and 8 effects of delays in Nigeria using the mean index score (MIS). Sunjka and Jacob [41] examined 38 causes and 8 effects of project delays in the Niger Delta region 
of Nigeria. Ojoko et al. [33] adopted the same method for analysing 32 causes and 10 effects of delay in Nigeria, the main results of these 3 studies were as follow: Inadequate planning, poor contract management, inappropriate design, poor communication and coordination, and slow decision-making were the most critical causes of delay in Nigeria. On the other hand, time and cost overruns, poor quality, disputes, bad public relations, arbitration, litigation and claim, total abandonment, and reduced profit were the most significant effects of delay in Nigeria.

In their study of the causes and effects of delay in Ghana, Amoatey et al.[6], have reported that the factors behind delays in Ghana were those related to financial problems, besides, cost overrun, time overrun, litigation, arbitration, and lack of continuity by the client were the 5 most significant effects.

In 2016, Khair et al. [23] designed a questionnaire survey to find the critical causes and effects of delay and the effective methods of minimizing delays in the road construction projects in Sudan. The findings reveal that the shortage of resources and the payment difficulties were the most important causes of delay, and that cost overrun and time overrun were the main results of delay. Also, Khair et al. [23] pointed out that the effective methods of minimizing delays were found to be the choice of project managers with sufficient experience and knowledge in project management and the use of proper techniques for projects. Similar findings were also reported by Obodoh [31] in their study of causes, effects and the methods of delay reduction in Nigeria. Also, Nyoni [30] investigated the causes and effects of delays in construction project in Zimbabwe, and their results were in the line with Khair et al. [23]. In Libya, Kuşakc1 et al. [25] performed a study that aimed at evaluating the causes and effects of delay in oil construction project. The output of the study discloses that security problems, material shortage, and construction method were the leading factors to construction delay. Whilst, cost and time overrun, disputes, total abandonment and arbitrage were the common results of delay in Libya. Furthermore, Gebrehiwet and Luo [17] carried out a questionnaire survey to investigate the typical causes of delay and its effects at different stages of construction (pre-construction, construction, and post-construction) in the Ethiopian projects. According to the study outcome cost overrun, time overrun, arbitration, contract termination, and litigation were the critical effects of delay. In addition, the study indicates that the construction phase is greatly influenced, followed by the pre-construction and post-construction phases. In another related study, Mukuka et al. [27] have using the mean item score (MIS) to assess the effects of schedule overruns on construction projects in the Gauteng province of South Africa. The finding shows that the ten major effects of schedule overrun were extension of time, cost overruns, loss of profit, poor quality of work, disputes, claims, creates stress to the client, bad reputation with the construction team, acceleration losses, and delay in getting profit by the client. To measure the 
effects of delay in construction projects of Punjab-Pakistan, Haq et al. [19] conducted a study based on a questionnaire survey administered to 37 construction firms, various statistical tools have been applied for data analysis and inference. The results show that delay in construction has significant effects and contributes to $75 \%$ of cost overrun, $72 \%$ of time overrun, and $31 \%$ of project abandonment. Moreover, Gbahabo and Ajuwon [16] conducted a qualitative study to provide a conceptual overview of project overruns in Sub-Saharan Africa. The findings of the research show that project overruns can have a damaging economic effect including allocative inefficiency of scarce resources, further delays, contractual disputes, litigation, claims, project failure, and total abandonment. Similarly, Ullah et al. [45] investigated 17 effects of delays in Malaysian building projects by conducting a questionnaire survey among the key project participants. It was revealed that: time overrun, cost overrun, loss of profit, poor quality of work, dispute, claim, arbitration, litigation, contract termination, and total project abandonment were the main effects of delays in Malaysian building projects. A comparison with other countries enabled them to disclose that the top five effects of delay in Malaysia also found in different developing countries. In their study of the causes effects of delay on project delivery time in Somalia Salah and Ahmed [38] have found that time overrun, disputes between parties involved, increase in the final cost of project, and reduced profit were the most prominent effects of delays. For their side, Oshungade and Kruger [34] have made a comparative study of causes and effects of delays and disruption in the South African construction industry. They start first by identifying the main causes and effects of delay in South Africa using the frequency, the severity and the importance's indices. Out of 48 identified causes 16 have emerged as important among them strikes, rework, shortage of materials, suspension of work, and poor communication. Likewise the 5 effects that found to be crucial were; create stress on contractor, cost overrun, time overrun, poor quality, and disputes. A comparison of the top causes and effect in South Africa with other African countries allows them to conclude that out of the 16 major, five causes were found to be unique to South African construction projects. In contrast only 2 effects (create stress on contractor and poor quality) were found to be specific to the South African construction projects. In more recent years, Serani and Bayeh [42] have studied the causes and the effects of delay in building construction in Ethiopia using the frequency, the severity and the importance indices, and they found that economic condition, fluctuation in the price, improper planning, slow decision making were the main cause of delay. And that time and budget overruns, poor quality, wastage and underutilization of human and material resources, abandonment of building projects were the top effects of delays in Ethiopia. Further, Rashid [37] have developed 11 hypotheses to test 'the impact of 7 identified factors of delay in Pakistani construction' on 'project delay' and then, the impact of 'delay' on '4 identified effects'. Structural 
equation modelling (SEM) and multiple regressions were applied to test the 11 hypotheses. The results show that: factors related to contractor, consultant, client, material, and equipment have significant impact on project delay, while the impact of general and labour factors were found to be insignificant. Also, the findings disclose that delay has significant positive effect on all the identified effects, and that delay causes $75 \%$ of cost overrun, $72 \%$ of time overrun, $67 \%$ of litigation, and $31 \%$ of project abandonment. In Algeria, despite the efforts made by the State in the field of construction, delays continue to be recorded, and these have multitude negative effects on projects and its participating parties. In spite of that, very few studies have investigated the problem of delay in Algerian construction projects. The study conducted recently by Rachidet al. [36] was focused on the identification of factors causing delay in Algeria with no attention to the effects of delay. So there is an acute necessity to measure the effects of delay in Algeria. Based on the aforementioned studies we summarize as follows:

- The majority of scholars have used the effects identified by (Aibinu and Jagboro [3] as base of their studies.

- The previous studies on the effects of delay on construction projects were limited to a minimum number of effects (the most exhaustive list was that of Kikwasi [24] with 20 items).

- The relative importance index (RII) was the most used techniques in analysing the effects of delays (see figure 1).

- None of the previous studies have categorized the effects of delay into main groups.

- None of the previous studies have studied the causal relationship between the effects of delay.

- None of the previous studies have studied the effect of delay in Algeria.

Therefore, to fill these gaps, the present study is designed to make a comprehensive list of the effects of delay and to assess the relative importance of these effects in the context of the Algerian construction projects (using the most popular technique found in literature (RII)). Also, as an important contribution we have categorized the identified effects into main groups using the factor analysis technique. Another contribution of this research to the existing literature is to test the relationship between the identified groups of effects using the SMART - PLS method.

To the best of our knowledge, this study is pioneering in the area of project management in Algeria, with a focus on the effects of delay in construction projects; as no previous research has identified the effects of construction delays in Algeria. 


\section{Techniques used to rank delay effects in previous studies}

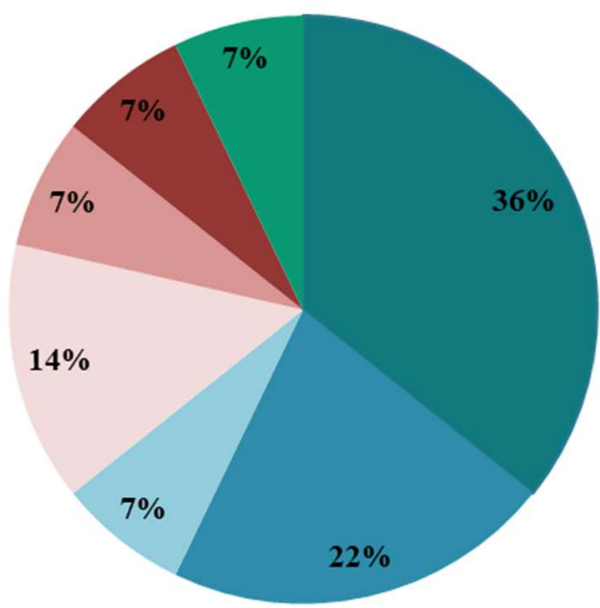

RII $\square$ MIS $\backsim$ Statistical tools $\backsim$ FI $\backsim$ SI $\backsim$ IMPI $\backsim$ SEM

Fig. 1.Techniques used to rank delay effects in previous studies

RII: relative importance index, MIS: mean items score, FI: frequency index, SI: severity index, IMPI: importance index

\section{RESEARCH OBJECTIVES}

This study seeks to accomplish the following objectives:

- To identify the effects of delay in Algerian construction projects;

- To assess the relative importance of these effects;

- To study the difference between the perceptions of the major project stockholders (project owners, consultants, contractors);

- To uncover any underlying interrelationship existing among the effects of delay in terms of importance;

- To test the relationship among the groups of effects;

- To compare the top 10 effects of delay in Algeria with other countries.

\section{RESEARCH METHODOLOGY}

A questionnaire survey was developed to assess the perceptions of owners, consultants, and contractors on the significant effects of delay in the Algerian 
construction project. A comprehensive list of 31 effects was identified through literature reviews and from interviews with specialists on the field of construction (Table 1 shows the identified effects and their codes). Afterward, respondents were asked to give their perceptions on the level of importance of these effects. To determine whether there is an agreement among the three groups in their assessments of the effects of delay, one way ANOVA was used. Further, the technique of factor analysis was performed in order to categorize the effects of delay. And, the SMART-PLS method was applied to test the relationship among the groups of effects.

Table 1. Effects of Delay in Algeria

\begin{tabular}{|l|l|}
\hline Effect ID & \\
\hline E1 & Cost overrun \\
\hline E2 & Additional cost of equipment and increased labour \\
\hline E3 & Tying down of client capital due to non-completion of the project \\
\hline E4 & Negative impact on the economy of the country \\
\hline E5 & Aging of the project before its delivery \\
\hline E6 & Time overrun \\
\hline E7 & Delaying the functioning beginning of the project and the use of space \\
\hline E8 & Poor quality \\
\hline E9 & Impact on the structure sustainability \\
\hline E10 & Wastage and underutilisation of human and material resources \\
\hline E11 & Reducing the corporate profit margin of contractors \\
\hline E12 & Failure of the company \\
\hline E13 & A penalty of delay on the company \\
\hline E14 & Bad public relations \\
\hline E15 & Social problem especially in the case of housing \\
\hline E16 & Loss of belief of citizens \\
\hline E17 & Negative public perception \\
\hline E18 & Dissatisfaction of all parties involved \\
\hline E19 & Frustration of the various stakeholders \\
\hline E20 & Litigation and claims \\
\hline E21 & Dispute between the parties involved \\
\hline E22 & Loss of productivity \\
\hline E23 & Loss of Job and Income \\
\hline E24 & Suspension of work \\
\hline E25 & Disruption of work \\
\hline E26 & Contract termination \\
\hline E27 & Total abandonment \\
\hline E28 & Disruption of the program \\
\hline E29 & Failure of the project \\
\hline E30 & Non-achievement of objectives \\
\hline E31 & Negative impact on the image of the city \\
\hline
\end{tabular}




\section{QUESTIONNAIRE DESIGN}

Data were gathered through a questionnaire survey. The questionnaire was divided into two main parts:

- The first part requested background information about the respondents (sex, age, position, years of experience, labour organization).

- The second part of the questionnaire focused on the effects of delay in the Algerian construction project. An ordinal five-point Likert scale ranged from 1: very low to 5: very important, was adopted to assess the relative importance of each effect of delay as perceived by the respondents.

A multitude of methods of distribution has been used to ensure the fast spread of the questionnaire: questionnaires sent by email, hard copy personally handed out, and via interviews. In addition, to get the trust of the surveyed participants and to promote the response rate, we have assured the participants that all the information gathered will be kept strictly confidential, and we have promised them to ensure their anonymity and to share with them the results of our study. The questionnaire survey was started in October 2018 in Algeria; over three months, 114 questionnaires were returned representing a response rate of $71.25 \%$. This was considered adequate for the analysis based on Moser and Katlon's affirmation (as cited in Aibinu and Jagboro [3]) 'the result of a survey could be considered as biased and of little value if the return rate was lower than 30-40\%'.

\section{ANALYTICAL APPROACH}

The collected data were analysed using the relative importance index (RII) as stated by many researchers $[3,17,23,24,25,31,30,39,45]$

$$
R I I=\frac{\sum a n}{N}
$$

Where:

$a$ is a constant that expresses the weight given to each effect, varies from 1 to 5 . $n$ is the response frequency. And $N$ is the total number of respondents.

\section{DISCUSSION AND RESULTS}

\subsection{Respondents' profiles}

A total number of 160 questionnaires were distributed to public and private practitioners in construction projects in Algeria. 114 completed responses were collected, 62 responses $(54.5 \%)$ were from the public sector, and 52(45.6\%) were from the private sector. The respondents included: 21 project owners, 44 
consultants, and 49 contractors. The majority of respondents ( $74.6 \%)$ belong to the age group between 25 and 40 years old; $50.9 \%$ of respondents have more than 5 years of experience (among them: $30.7 \%$ have an experience that ranged from 5 to 10 years, $12.3 \%$ have between 10 and 15 years of experience and $7.9 \%$ have more than 15 years of experience). Table 2 summarizes the status of the respondents.

Table 2.The respondents' profiles

\begin{tabular}{|l|c|c|}
\hline Description & Frequency & Percentage \\
\hline Age & 17 & $14.9 \%$ \\
[20- 25[ & 85 & $74.6 \%$ \\
[25- 40[ & 12 & $10.5 \%$ \\
40 and older & 114 & $100 \%$ \\
TOT & 43 & $37.7 \%$ \\
Position & 31 & $27.2 \%$ \\
\hline Architect & 27 & $23.7 \%$ \\
Civil engineer & 13 & $11.4 \%$ \\
Project Manager & 114 & $100 \%$ \\
Others & \multicolumn{2}{|}{} \\
TOT & 62 & $54.4 \%$ \\
Public & 52 & $45.6 \%$ \\
Private & 114 & $100 \%$ \\
\hline TOT & 56 & $49.1 \%$ \\
\hline Sector & 35 & $30.7 \%$ \\
TOT & 14 & $12.3 \%$ \\
Less than 5years & 9 & $7.9 \%$ \\
[10-15] & 114 & $100 \%$ \\
\hline Over 15 years & 21 & $18.4 \%$ \\
TOT & 44 & $38.6 \%$ \\
\hline Owner & 114 & $100 \%$ \\
\hline Consultant &
\end{tabular}

\subsection{Reliability of the questionnaire}

Cronbach's alpha was measured to test the reliability of the questionnaire and to determine the internal consistency of 31 elements. According to Santos and Reynaldo [40], 'an alpha value of Cronbach greater than 0.7 implies that the instrument is acceptable'; as given in Table 3 the value of Cronbach's alpha was 0.896 , which ensures that there are internal consistency and good reliability of the questionnaire. 
Table 3.Cronbach's Alpha for Effects of Construction Delays

\begin{tabular}{|c|c|}
\hline \multicolumn{2}{|c|}{ Reliability statistics } \\
\hline Cronbach's Alpha & Number of elements \\
\hline 0.896 & 31 \\
\hline
\end{tabular}

\subsection{Statistical test of the questionnaire's}

In order to check the questionnaire results', we have carried out one sample t-test of student. This test is commonly used to affirm the correspondence of the samples means with that of the target population, or to test the statistical difference between the sample mean and the sample midpoint of the test variable. So, to know the level of importance of the 31 identified effects, we use the mean 3 $((1+2+3+4+5) / 5=3)$.

Hence, for this study we accept that:

- The delay has a high impact on the effect $X$, if the p-value $<5 \%$;

- The point relative of the high importance was greater than 3;

- And the most important is that the mean of the X effects was within the confidence interval.

From the Table 4, the results show that the p-value is inferior to $5 \%$ and the mean differences of the $\mathrm{X}$ effects are within the confidence interval, so the results of the questionnaire can be used and generalized.

\subsection{Evaluation of the effects of delay}

The effects of construction delay were ranked according to their relative importance index, and the rank of the 31 effects is given in Table 5. 
Table 4. One sample t-test

\begin{tabular}{|c|c|c|c|c|c|c|c|c|c|c|}
\hline \multirow{3}{*}{ ID } & \multicolumn{4}{|c|}{ Descriptive statistics } & \multicolumn{6}{|c|}{ Test Value $=3$} \\
\hline & \multirow{2}{*}{$\mathrm{N}$} & \multirow{2}{*}{ Mean } & \multirow{2}{*}{ SD } & \multirow{2}{*}{ SEM } & \multirow{2}{*}{$\mathrm{t}$} & \multirow{2}{*}{ df } & \multirow{2}{*}{$\begin{array}{c}\text { Sig. } \\
\text { (2-tailed) }\end{array}$} & \multirow{2}{*}{ MD } & \multicolumn{2}{|c|}{$95 \% \mathrm{CID}$} \\
\hline & & & & & & & & & Upper & Lower \\
\hline E1 & 114 & 3.877 & 1.082 & 0.101 & 8.656 & 113 & 0.000 & 0.877 & 0.676 & 1.078 \\
\hline E2 & 114 & 3.421 & 0.940 & 0.088 & 4.784 & 113 & 0.000 & 0.421 & 0.247 & 0.595 \\
\hline E3 & 114 & 3.553 & 1.065 & 0.100 & 5.540 & 113 & 0.000 & 0.553 & 0.355 & 0.750 \\
\hline E4 & 114 & 3.763 & 1.108 & 0.104 & 7.357 & 113 & 0.000 & 0.763 & 0.558 & 0.969 \\
\hline E5 & 114 & 3.570 & 1.160 & 0.109 & 5.250 & 113 & 0.000 & 0.570 & 0.355 & 0.785 \\
\hline E6 & 114 & 4.132 & 0.917 & 0.086 & 13.175 & 113 & 0.000 & 1.132 & 0.961 & 1.302 \\
\hline E7 & 114 & 3.588 & 1.071 & 0.100 & 5.859 & 113 & 0.000 & 0.588 & 0.389 & 0.786 \\
\hline E8 & 114 & 3.789 & 1.093 & 0.102 & 7.713 & 113 & 0.000 & 0.789 & 0.587 & 0.992 \\
\hline E9 & 114 & 3.456 & 1.277 & 0.120 & 3.814 & 113 & 0.000 & 0.456 & 0.219 & 0.693 \\
\hline E10 & 114 & 3.675 & 1.109 & 0.104 & 6.503 & 113 & 0.000 & 0.675 & 0.470 & 0.881 \\
\hline E11 & 114 & 3.474 & 1.049 & 0.098 & 4.820 & 113 & 0.000 & 0.474 & 0.279 & 0.668 \\
\hline$\overline{E 12}$ & 114 & 3.588 & 1.196 & 0.112 & 5.247 & 113 & 0.000 & 0.588 & 0.366 & 0.810 \\
\hline E13 & 114 & 3.430 & 1.255 & 0.118 & 3.657 & 113 & 0.000 & 0.430 & 0.197 & 0.663 \\
\hline E14 & 114 & 3.289 & 1.142 & 0.107 & 2.706 & 113 & 0.008 & 0.289 & 0.078 & 0.501 \\
\hline$\overline{\text { E15 }}$ & 114 & 3.544 & 1.198 & 0.112 & 4.846 & 113 & 0.000 & 0.544 & 0.321 & 0.766 \\
\hline E16 & 114 & 3.342 & 1.196 & 0.112 & 3.054 & 113 & 0.003 & 0.342 & 0.120 & 0.564 \\
\hline E17 & 114 & 3.307 & 1.213 & 0.114 & 2.703 & 113 & 0.008 & 0.307 & 0.082 & 0.532 \\
\hline E18 & 114 & 3.6 & 1.0 & 0.095 & 6.399 & 113 & 0.000 & 0.605 & 0.418 & 0.793 \\
\hline E19 & 114 & 3.535 & 0.933 & 0.087 & 6.124 & 113 & 0.000 & 0.535 & 0.362 & 0.708 \\
\hline E20 & 114 & 3.368 & 0.989 & 0.093 & 3.977 & 113 & 0.000 & 0.368 & 0.185 & 0.552 \\
\hline E21 & 114 & 3.553 & 1.065 & 0.100 & 5.540 & 113 & 0.000 & 0.553 & 0.355 & 0.750 \\
\hline E22 & 114 & 3.693 & 1.040 & 0.097 & 7.113 & 113 & 0.000 & 0.693 & 0.500 & 0.886 \\
\hline E23 & 114 & 3.518 & 0.998 & 0.093 & 5.539 & 113 & 0.000 & 0.518 & 0.332 & 0.703 \\
\hline E24 & 114 & 3.404 & 1.111 & 0.104 & 3.878 & 113 & 0.000 & 0.404 & 0.197 & 0.610 \\
\hline E25 & 114 & 3.596 & 1.002 & 0.094 & 6.356 & 113 & 0.000 & 0.596 & 0.411 & 0.782 \\
\hline E26 & 114 & 3.474 & 1.305 & 0.122 & 3.876 & 113 & 0.000 & 0.474 & 0.232 & 0.716 \\
\hline E27 & 114 & 3.377 & 1.359 & 0.127 & 2.963 & 113 & 0.004 & 0.377 & 0.125 & 0.629 \\
\hline E28 & 114 & 3.649 & 1.004 & 0.094 & 6.901 & 113 & 0.000 & 0.649 & 0.463 & 0.835 \\
\hline E29 & 114 & 3.763 & 1.162 & 0.109 & 7.012 & 113 & 0.000 & 0.763 & 0.548 & 0.979 \\
\hline E30 & 114 & 3.912 & 1.018 & 0.095 & 9.568 & 113 & 0.000 & 0.912 & 0.723 & 1.101 \\
\hline E31 & 114 & 3.711 & 1.260 & 0.118 & 6.020 & 113 & 0.000 & 0.711 & 0.477 & 0.944 \\
\hline
\end{tabular}

SD: Std. Deviation. SEM: Std. Error Mean. MD: Mean Difference. CID: Confidence interval of the difference 

PROJECTS: AN EMPIRICAL STUDY

Table 5. RII and ranking of the effects of construction delay

\begin{tabular}{|c|c|c|c|c|c|c|c|c|}
\hline \multirow{2}{*}{ ID } & \multicolumn{2}{|c|}{ Owners } & \multicolumn{2}{c|}{ Consultants } & \multicolumn{2}{c|}{ Contractors } & \multicolumn{2}{c|}{ Overall } \\
\cline { 2 - 9 } & Rank & RII & Rank & RII & Rank & RII & Rank & RII \\
\hline E1 & 9 & 3.48 & 2 & 4.07 & 5 & 3.88 & 3 & 3.88 \\
\hline E2 & 24 & 3.14 & 14 & 3.64 & 29 & 3.35 & 25 & 3.42 \\
\hline E3 & 17 & 3.33 & 17 & 3.52 & 15 & 3.67 & 17 & 3.55 \\
\hline E4 & 7 & 3.52 & 7 & 3.77 & 6 & 3.86 & 6 & 3.76 \\
\hline E5 & 10 & 3.48 & 26 & 3.39 & 8 & 3.78 & 15 & 3.57 \\
\hline E6 & 1 & 3.90 & 1 & 4.16 & 1 & 4.20 & 1 & 4.13 \\
\hline E7 & 4 & 3.62 & 9 & 3.70 & 27 & 3.47 & 14 & 3.59 \\
\hline E8 & 3 & 3.76 & 10 & 3.70 & 4 & 3.88 & 4 & 3.79 \\
\hline E9 & 29 & 3.05 & 23 & 3.45 & 17 & 3.63 & 23 & 3.46 \\
\hline E10 & 21 & 3.29 & 5 & 3.77 & 10 & 3.76 & 9 & 3.68 \\
\hline E11 & 30 & 3.00 & 19 & 3.50 & 16 & 3.65 & 22 & 3.47 \\
\hline E12 & 28 & 3.05 & 8 & 3.75 & 14 & 3.67 & 13 & 3.59 \\
\hline E13 & 26 & 3.10 & 20 & 3.48 & 25 & 3.53 & 24 & 3.43 \\
\hline E14 & 20 & 3.29 & 31 & 3.22 & 28 & 3.35 & 31 & 3.29 \\
\hline E15 & 14 & 3.38 & 12 & 3.64 & 24 & 3.53 & 18 & 3.54 \\
\hline E16 & 19 & 3.29 & 22 & 3.48 & 31 & 3.24 & 29 & 3.34 \\
\hline E17 & 16 & 3.33 & 29 & 3.34 & 30 & 3.27 & 30 & 3.31 \\
\hline E18 & 8 & 3.48 & 13 & 3.64 & 20 & 3.63 & 11 & 3.61 \\
\hline E19 & 6 & 3.57 & 25 & 3.41 & 18 & 3.63 & 19 & 3.54 \\
\hline E20 & 31 & 2.81 & 27 & 3.34 & 19 & 3.63 & 28 & 3.37 \\
\hline E21 & 22 & 3.24 & 24 & 3.45 & 9 & 3.78 & 16 & 3.55 \\
\hline E22 & 23 & 3.24 & 16 & 3.59 & 3 & 3.98 & 8 & 3.69 \\
\hline E23 & 18 & 3.33 & 18 & 3.50 & 21 & 3.61 & 20 & 3.52 \\
\hline E24 & 15 & 3.38 & 30 & 3.25 & 22 & 3.55 & 26 & 3.40 \\
\hline E25 & 5 & 3.57 & 21 & 3.48 & 12 & 3.71 & 12 & 3.60 \\
\hline E26 & 27 & 3.10 & 15 & 3.59 & 23 & 3.53 & 21 & 3.47 \\
\hline E27 & 25 & 3.14 & 28 & 3.34 & 26 & 3.51 & 27 & 3.38 \\
\hline E28 & 13 & 3.38 & 11 & 3.66 & 11 & 3.76 & 10 & 3.65 \\
\hline E29 & 12 & 3.43 & 3 & 3.89 & 7 & 3.80 & 5 & 3.76 \\
\hline E30 & 2 & 3.86 & 6 & 3.77 & 2 & 4.06 & 2 & 3.91 \\
\hline E31 & 11 & 3.43 & 4 & 3.86 & 13 & 3.69 & 7 & 3.71 \\
\hline
\end{tabular}

\subsubsection{The 10 most important effect of delay from the overall view of respondents}

As shown in Figure 2, the top 10 effects of delay in Algerian construction project were:

1) Time overrun: all the three parts agreed to classify 'time overrun' as the first most important effect with an importance index of 4.14; when projects are delayed, more days of work is required to finish the execution of the project, as a 
result, the prescribed delivery time is extended and the project is said to have experienced time overrun $[19,41]$. This result was supported by various researches $[1,3,15,24,28,30,31,33,35,37,39,41,45]$ in which 'time overrun' was the first most important effect of delay.

2) Non-achievement of objectives: is the second effect with an importance index of 3.91; this effect was also classified as the $2^{\text {nd }}$ for both contractors and owners; however, the consultants ranked it the $6^{\text {th }}$ with $\mathrm{RII}=3.77$. Delays in construction projects will conduct to failure in accomplishment project with the contract specifications and objectives and failure in achieving the triple constraint of the project (time, cost, and quality).

3) Cost overrun: is the third effect with $\mathrm{RII}=3.88$; this effect was also ranked first in several studies $[6,17,19,23,25,42]$. Delays are frequently accompanied by cost overrun[46]; when projects are delayed, two possible scenarios can happen; the first one is that works will be expedited to avoid the late delivery of the project by deploying more resources and duplicating the hours of works as a result, an extra cost will be generated, the second is that the scheduled time for the completion of the project, is postponed, and more days of work were added leading to additional labour, machine and equipment cost and resulting to an escalation in project cost' [19].

4) Poor quality: is the fourth effect from the overall ranking with RII of 3.79 , (the $3^{\text {rd }}$ effect in the perception of owners, the $4^{\text {th }}$ in the view of contractors, and the $10^{\text {th }}$ in the regard of consultants). Generally, a delayed construction project results in a decrease in quality and safety [8]; when a project is delayed contractors try to harry the project in order to minimize the loss and to avoid more additional cost by seeking more manpower with the least salary and this by the employment of unskilled manpower; as a consequence, this leads to errors or mistakes during construction and bad quality work. Also, delays cause disturbance of work and loss of productivity which may affect the quality of work. This result was in the line with $[15,24,34,41,42,45]$ who also perceive poor quality as a major effect of delays.

5) Failure of the project: received $5^{\text {th }}$ from the overall ranking with RII of 3.76 ; a successful project is one that has reached its triple constraints of time, cost, and quality $[15,28]$. Delay in construction project causes time overrun $[1,3,15,17$, $19,27,33,35,39,41,45]$, cost overrun[1, 3, 6, 15, 16, 24, 25, 27, 39, 41, 42, 45], poor quality $[15,17,34,41,42,45]$, non-achievement of objectives and thus failure of the project. This result was supported by [16]

6) Negative impact on the economy of the country: is the $6^{\text {th }}$ effect with an index of 3.76. Timely completion of construction project within budget and according to the contract specifications will contribute to the economic development, since it allows creating more job and income, increasing the profitability (given that it constitutes a continuous and sustainable investment) and optimizing the 
attractiveness. Losses caused by delay can affect the entire economy [44]; given that delay in construction project disrupts the program, leads to the late opening of the project which delays the functioning beginning of the project, causes loss of job and revenue, freezes the investment, and send negative signals to foreign investors thereby slowing down the national development [29].

7) Negative impact on the image of the city: is ranked $7^{\text {th }}$ with an importance relative of 3.71. Project construction enhances space as it transforms the city, gives more visibility, maximizes attractiveness, and promotes tourism. Delay in construction projects has a direct influence on the quality of the structure, and significant consequences on the visual appearance of the city; that gives a negative impact on the image of the city, and 'bad impression to foreign visitors' [19].

8) Loss of productivity: is the $8^{\text {th }}$ effect with $\mathrm{RII}=3.69$. Delay disrupts the construction work that is why contractors seek to make up for these delays by the acceleration of the activities on-site, either by:

- Increasing hours of work: 'the project stakeholders tend to speed up the workflow which may increase the workloads on labours, so that may generate stress, mental and physical fatigue, and discouragement of employees' [10]; this can lead to tiredness, a drop in morale and motivation, and an increase in accident and absenteeism rates; as workers are accustomed to spending effort and energy at a specified rate and all these will conduct to decrease in the level of productivity. - Increased staff and co-activity: this leads to congestion in the construction site, interference between teams, interruptions of work, the difficulty of supervision, and disruption of productivity.

9) Wastage and underutilisation of human and material resources: is the $9^{\text {th }}$ effect with RII= 3.68; the challenge of contractors is to use resources effectively to reduce time and cost and to get more profitability. Failure to complete construction projects within targeted time can lead to 'wastage and underutilisation of human and material resources' [16, 35]. When project is completed at the recorded time and with the stipulated amount, it will free up resources for other use, when a project is delayed, manpower wants to free up them-selves and not be stuck by this project, by looking for work in other building sites to earn more money and income. This result was also concluded by some researchers [16, 24, 35, 42].

10) Disruption of the program: is ranked $10^{\text {th }}$ (with $\mathrm{RII}=3.65$ ). Project programming is the act of programming a set of actions and operations that are expected to be done in planned time and according to a specific plan to meet specific goals, delays in construction projects will lead to loss of productivity, and delay the functioning beginning of the project which disrupts the program and causes an imbalance between supply and demand. This result was not stated by any of the investigated studies. 


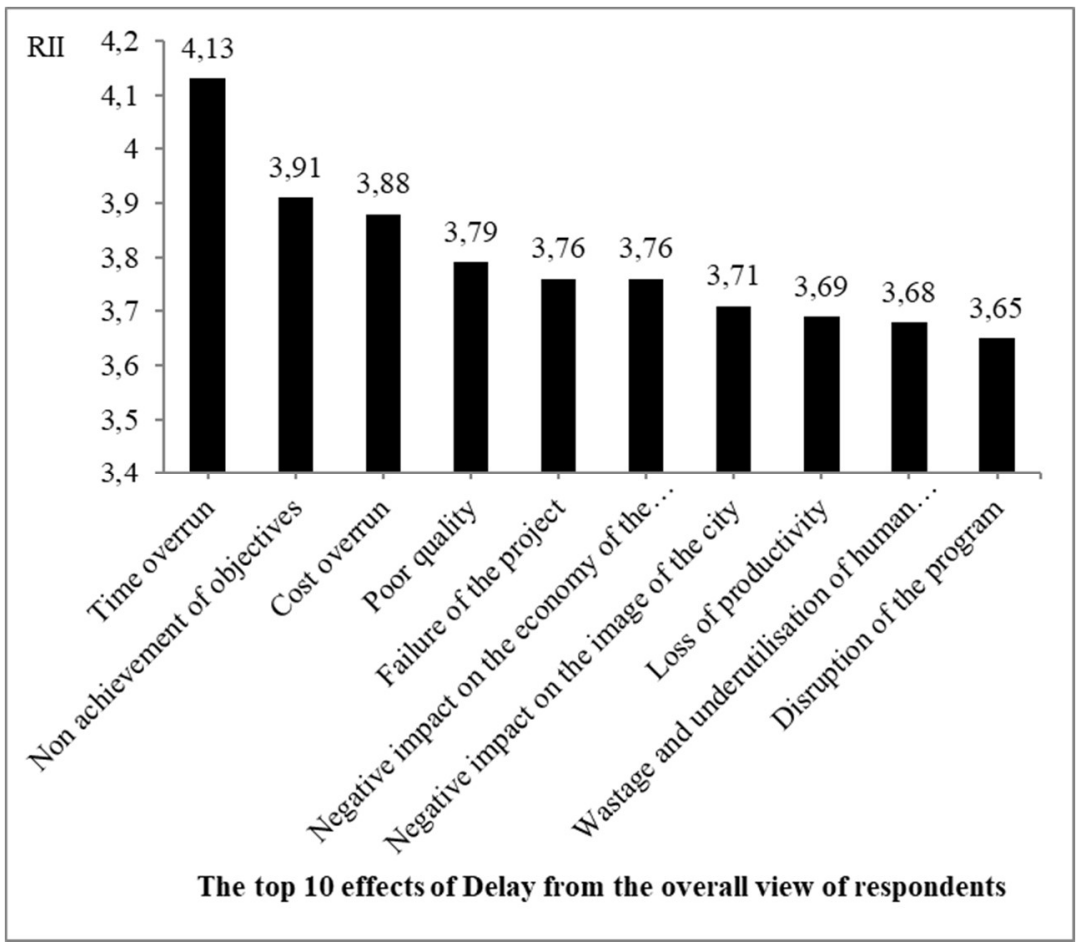

Fig. 2. The top 10 effects of Delay from the overall view of respondents

\subsubsection{The 10 major effects of delays from the views of the major project stockholders}

The 10 main effects of delays from the perception of the major stakeholders (owners, consultants, contractors) were presented in the radars charts. In order to make the reading and the comparison easy, 3 zones of importance have been identified using the range value of the Likert scale as follows:

$$
A_{I}=\frac{X_{\max }-X_{\min }}{n}
$$

Where:

$A_{i}$ is the interval amplitude, $X_{\max }=5, X_{\min }=1$, and $n$ is the number of intervals (zones of importance $=3$ ). So the $\mathrm{A}_{\mathrm{i}}=1.33$

Table 6. Levels and zones of importance

\begin{tabular}{|c|c|c|}
\hline Scale & Level of importance & Zone \\
\hline$[1.00-2.33]$ & Low importance & Green \\
\hline$[2.34-3.66]$ & Moderate importance & Yellow \\
\hline$[3.67-5.00]$ & High importance & Red \\
\hline
\end{tabular}




\subsubsection{The 10 major effects of delays from the views of owners}

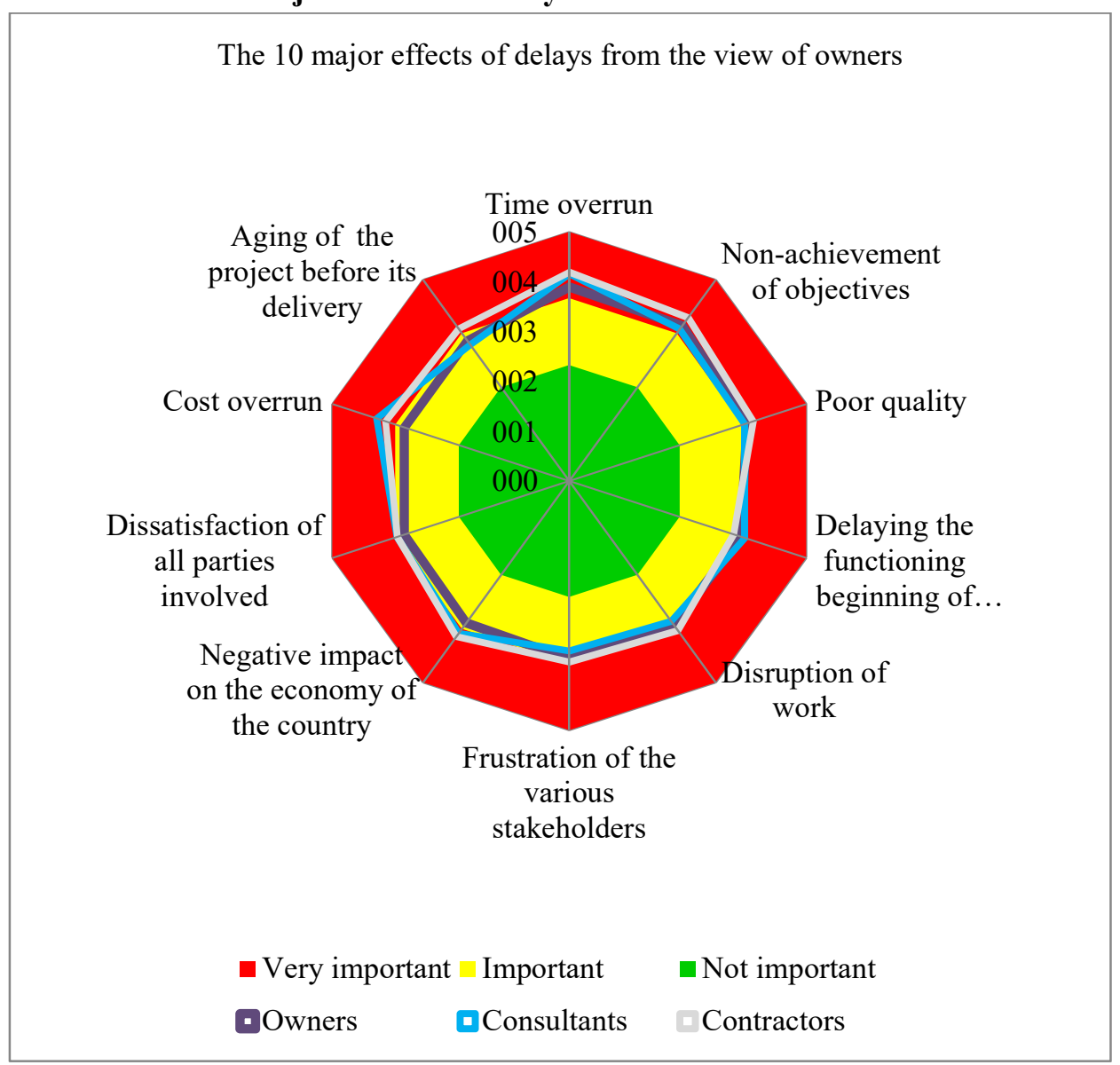

Fig. 3. The 10 major effects of delay from the view of owners

The 10 major effects from owners point of view was presented in the figure 3 , the perception of consultant and contractor regarding these effects were also presented in the same chart. The radar chart (figure 3) shows that out of 'the top 10 effects from the owner's view', 3 effects 'time overrun, non-achievement of objectives and poor quality' were classified as very important (red zone) by the owners, these effects were also found to be most critical for both consultants and contractors. The seven remaining effects were found in the moderate zone from owners' perception. This can be explained by the fact that owners give more consideration to the effects on traditional measures of success than the other measures. Comparing the perception of contractors with owners' perception, it can be seen that contractors perceived the 10 effects much higher than did the owners. And that 8 out of the 10 effects (identified by owners) were emphasized 
as very important from the opinion of contractors. This can be explained by the fact that contractors are highly affected by the effects of delays than owners. Regarding the perception of consultant, it can be seen that 6 out of the 10 major effects for owners were emphasized as very important from the views of consultants. While, 'time overrun, cost overrun, delaying the functioning beginning of the project and the use of space, negative impact on the economy of the country, dissatisfaction of all parties involved' were considered more important by consultants comparing to the owners' perspective.

\subsubsection{The $\mathbf{1 0}$ major effects of delays from the views of consultants}

Figure 4 depicts the 10 most important effects of delay as perceived by consultants. From this radar, it can be seen that consultants perceived all these effects as very important. The radar also displays the close opinions between contractors and consultants. The effect 'Delaying the functioning beginning of the project and the use of space' was rated as important from contractors' opinion, while the 9 other effects were classified as very important. From these nine; 'time overrun, non-achievement of objectives, negative impact on the economy of the country, and poor quality' were viewed more important from the view of contractors than the consultants' view. Contrarily, the perception of owners was less important than that of consultants for 9 effects. However, the radar chart displays that 'time overrun and poor quality' were ranked as very important, and that 'poor quality' was rated slightly better for owners than for consultants.

\subsubsection{The 10 major effects of delays from the views of contractors}

Figure 5 presents the 10 main effects of delay according to the contractors' viewpoint; as can be viewed, all the 10 effects were critically important (in the red zone). Comparing the consultants' opinion with that of contractors, the radar reveals that 8 out of 10 effects were found very important from consultants view, among them 'failure of project' and 'cost overrun' were more important in the vision of consultant. However, the perception of importance from the owners' view was lower comparing to contractors' assessment. And only 3 items were classified highly important. 


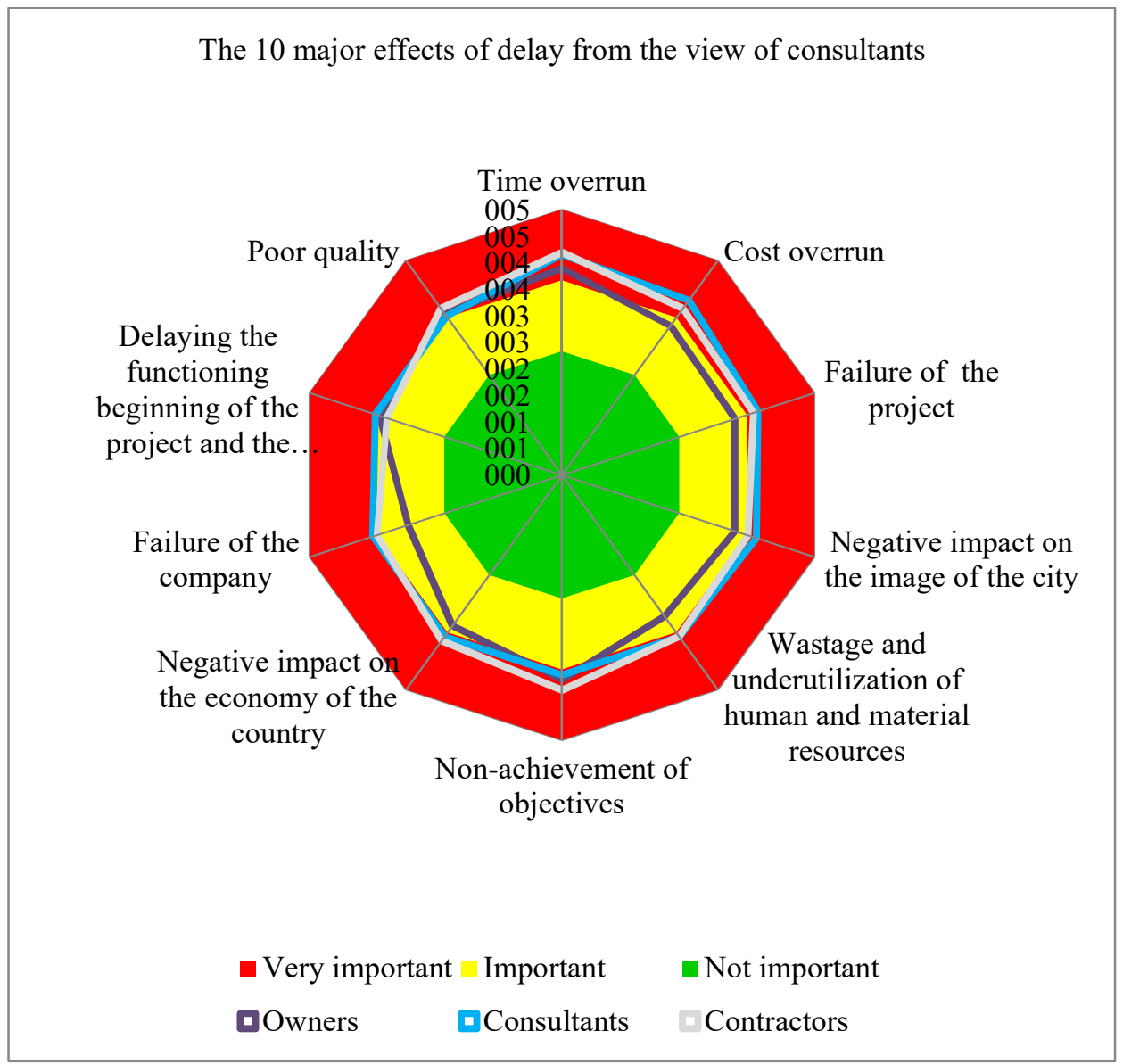

Fig. 4. The 10 major effects of delay from the view of consultants

From these 3 figures, it can be seen that five effects of delay were figured in the 3 radars: 'time overrun', 'non-achievement of objectives', 'poor quality', 'negative impact on the economy of the country', and 'cost overrun'. These effects were classed among the most prominent effects of delay from the overall view (see previous section). However, 'failure of the project', 'wastage and underutilisation of human and material resources' were found common between consultants and contractors, which can be explained by the fact that consultant and contractor work jointly especially in the phase of construction; so, it is very logical that they will share similar problems, which explain the convergent perceptions between them ( 7 out of 10 effects were found common between them). While 'delaying the functioning beginning of the project and the use of space' was common between owner and consultant. And 'aging of the project before its delivery' was the common effect between owners and contractors. From the 
results above, it is interesting to cross and compare the relative importance of each item as perceived by the three groups of respondents to test the degree of agreement between them. The next section is designed to compare the perceptions of owners, consultants, and contractors using 'the one way ANOVA test'.

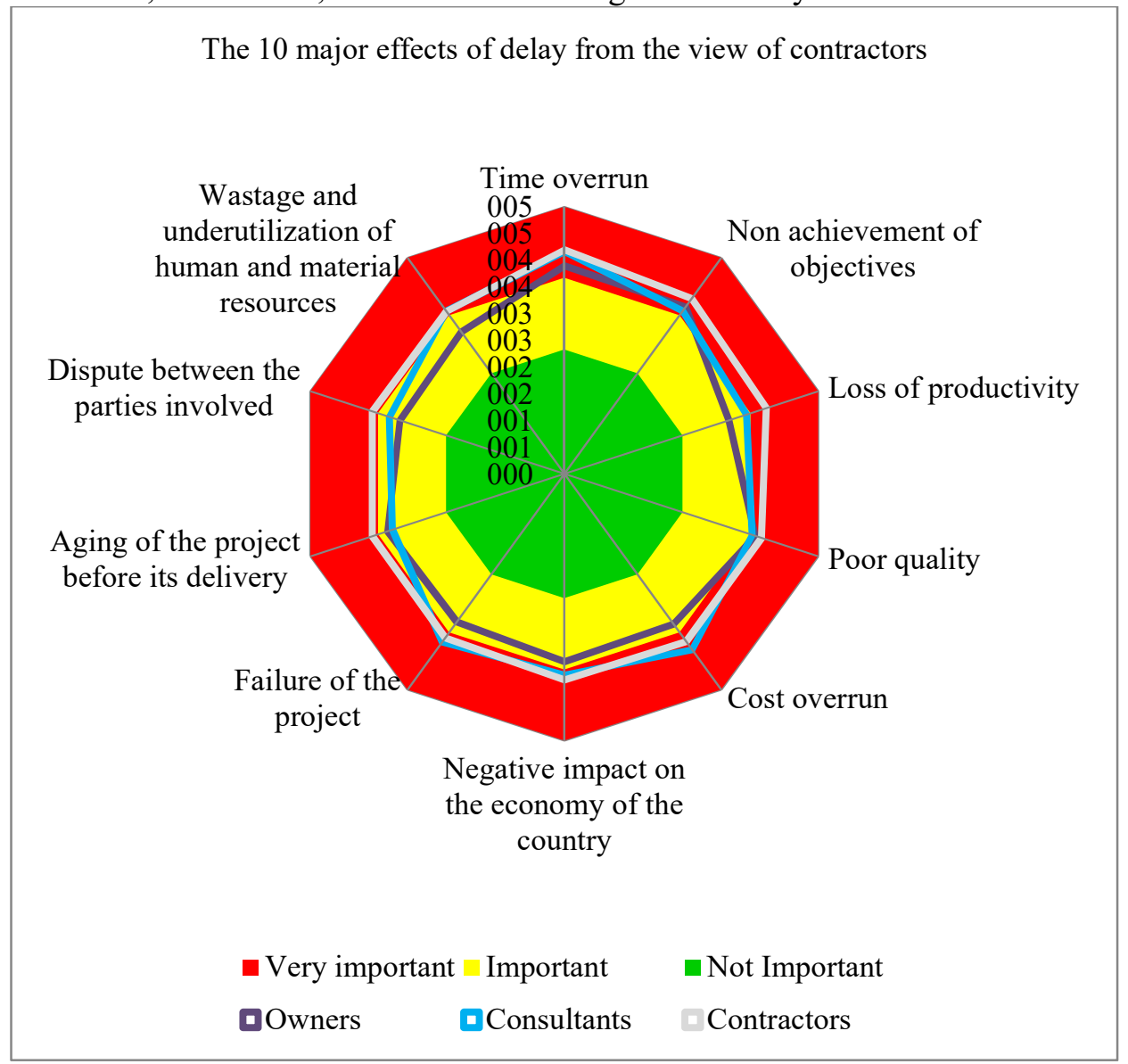

Fig. 5. The 10 major effects of delay from the view of contractors

\subsection{Difference in perception among the three groups}

'One way ANOVA' test is carried out to test if there is a significant difference (disagreement) between the three groups of respondents (owners, consultants, contractors) as to the effects of delay. Two hypotheses were proposed:

- Null hypothesis $\mathrm{H}_{0}$ : there is no significant difference (a good agreement) between the three groups (if the $\mathrm{p}$-value is greater than $5 \%$ ).

- Alternative hypothesis $\mathrm{H}_{1}$ : there is a significant difference (disagreement) between the 3 groups (if the p-value is inferior to $5 \%$ ). Table 7 illustrates the one 
way ANOVA results, which reveal a good agreement between the 3 groups as to 29 effects of delay, while, there is a significant difference between them for some delay effects (litigation and claims 'E20' and loss of productivity 'E22').The PostHoc test "LSD" (least significant difference) was performed to look for the source of this difference and a $p$-value $<5 \%$ was considered significant. The results (as shown in Table 8) disclose that the 'owners' are the source of this difference regarding their perception of the relative importance of 'litigation and claims' $(\mathrm{RII}=2.80)$ which was different from the views of consultants $(\mathrm{RII}=3.34)$ and contractors $(\mathrm{RII}=3.63)$ who perceived it more critical. However, there are some slightly contrary opinions between the couple 'owners- contractors' concerning the relative importance of the effect 'loss of productivity' which was 3.63 and 3.98 respectively. Owners have a tendency to settle the disputes coming from delay amicably with no need to going to the courts of law for avoiding the mistrust and the additional cost accompanied. Contrarily, contractors see that delay has harsh consequences on the project and it often leads to a disagreement between the parties when requesting compensation; which gives rise to litigation and claims for solving the problem. Owners perceive that delay has an average effect on the loss of productivity and they ranked it in $23^{\text {rd }}$, while they accuse contractors of being responsible for these losses. In contrast, contractors assert that delay contributes directly to the loss of productivity and they ranked it as the $3^{\text {rd }}$ most important effect.

Table 7. One-Way ANOVA Test

\begin{tabular}{|c|c|c|c|c|c|c|c|}
\hline & Sum & Squares & $\mathrm{df}$ & Mean $^{2}$ & $\mathrm{~F}$ & Sig. & Decision \\
\hline \multirow{3}{*}{ E1 } & BG & 4.982 & 2 & 2.491 & \multirow{3}{*}{2.172} & \multirow{3}{*}{0.119} & \multirow{3}{*}{$\mathrm{H}_{0}$} \\
\hline & WG & 127.299 & 111 & 1.147 & & & \\
\hline & Total & 132.281 & 113 & & & & \\
\hline \multirow{3}{*}{ E2 } & BG & 3.934 & 2 & 1.967 & \multirow{3}{*}{2.278} & \multirow{3}{*}{0.107} & \multirow{3}{*}{$\mathrm{H}_{0}$} \\
\hline & WG & 95.855 & 111 & 0.864 & & & \\
\hline & Total & 99.789 & 113 & & & & \\
\hline \multirow{3}{*}{ E3 } & BG & 1.765 & 2 & 0.882 & \multirow{3}{*}{0.775} & \multirow{3}{*}{0.463} & \multirow{3}{*}{$\mathrm{H}_{0}$} \\
\hline & WG & 126.419 & 111 & 1.139 & & & \\
\hline & Total & 128.184 & 113 & & & & \\
\hline \multirow{3}{*}{ E4 } & BG & 1.640 & 2 & 0.820 & \multirow{3}{*}{0.665} & \multirow{3}{*}{0.517} & \multirow{3}{*}{$\mathrm{H}_{0}$} \\
\hline & WG & 136.965 & 111 & 1.234 & & & \\
\hline & Total & 138.605 & 113 & & & & \\
\hline \multirow{3}{*}{ E5 } & BG & 3.738 & 2 & 1.869 & \multirow{3}{*}{1.400} & \multirow{3}{*}{0.251} & \multirow{3}{*}{$\mathrm{H}_{0}$} \\
\hline & WG & 148.201 & 111 & 1.335 & & & \\
\hline & Total & 151.939 & 113 & & & & \\
\hline \multirow{3}{*}{ E6 } & BG & 1.371 & 2 & 0.686 & \multirow{3}{*}{0.813} & \multirow{3}{*}{0.446} & \multirow{3}{*}{$\mathrm{H}_{0}$} \\
\hline & WG & 93.655 & 111 & 0.844 & & & \\
\hline & Total & 95.026 & 113 & & & & \\
\hline
\end{tabular}




\begin{tabular}{|c|c|c|c|c|c|c|c|}
\hline \multirow{3}{*}{ E7 } & BG & 1.307 & 2 & 0.654 & \multirow{3}{*}{0.565} & \multirow{3}{*}{0.570} & \multirow{3}{*}{$\mathrm{H}_{0}$} \\
\hline & WG & 128.316 & 111 & 1.156 & & & \\
\hline & Total & 129.623 & 113 & & & & \\
\hline \multirow{3}{*}{ E8 } & BG & 0.713 & 2 & 0.357 & \multirow{3}{*}{0.295} & \multirow{3}{*}{0.745} & \multirow{3}{*}{$\mathrm{H}_{0}$} \\
\hline & WG & 134.234 & 111 & 1.209 & & & \\
\hline & Total & 134.947 & 113 & & & & \\
\hline \multirow{3}{*}{ E9 } & BG & 5.031 & 2 & 2.516 & \multirow{2}{*}{1.558} & \multirow{2}{*}{0.215} & \multirow{2}{*}{$\mathrm{H}_{0}$} \\
\hline & WG & 179.249 & 111 & 1.615 & & & \\
\hline & Total & 184.281 & 113 & & & & \\
\hline \multirow{3}{*}{ E10 } & BG & 3.917 & 2 & 1.959 & \multirow{2}{*}{1.609} & \multirow{2}{*}{0.205} & \multirow{2}{*}{$\mathrm{H}_{0}$} \\
\hline & WG & 135.074 & 111 & 1.217 & & & \\
\hline & Total & 138.991 & 113 & & & & \\
\hline \multirow{3}{*}{ E11 } & BG & 6.319 & 2 & 3.160 & \multirow{3}{*}{2.970} & \multirow{3}{*}{0.055} & \multirow{3}{*}{$\mathrm{H}_{0}$} \\
\hline & WG & 118.102 & 111 & 1.064 & & & \\
\hline & Total & 124.421 & 113 & & & & \\
\hline \multirow{3}{*}{ E12 } & BG & 7.645 & 2 & 3.822 & \multirow{3}{*}{2.756} & \multirow{3}{*}{0.068} & \multirow{3}{*}{$\mathrm{H}_{0}$} \\
\hline & WG & 153.978 & 111 & 1.387 & & & \\
\hline & Total & 161.623 & 113 & & & & \\
\hline & BG & 2.948 & 2 & 1.474 & & & \\
\hline E13 & WG & 174.991 & 111 & 1.576 & 0.935 & 0.396 & $\mathrm{H}_{0}$ \\
\hline & Total & 177.939 & 113 & & & & \\
\hline & BG & 0.332 & 2 & 0.166 & & & \\
\hline E14 & WG & 147.115 & 111 & 1.325 & 0.125 & 0.882 & $\mathrm{H}_{0}$ \\
\hline & Total & 147.447 & 113 & & & & \\
\hline & BG & 0.942 & 2 & 0.471 & & & \\
\hline E15 & WG & 161.338 & 111 & 1.453 & 0.324 & 0.724 & $\mathrm{H}_{0}$ \\
\hline & Total & 162.281 & 113 & & & & \\
\hline & BG & 1.334 & 2 & 0.667 & & & \\
\hline E16 & WG & 160.324 & 111 & 1.444 & 0.462 & 0.631 & $\mathrm{H}_{0}$ \\
\hline & Total & 161.658 & 113 & & & & \\
\hline & BG & 0.150 & 2 & 0.075 & & & \\
\hline E17 & WG & 166.104 & 111 & 1.496 & 0.050 & 0.951 & $\mathrm{H}_{0}$ \\
\hline & Total & 166.254 & 113 & & & & \\
\hline & BG & 0.429 & 2 & 0.215 & & & \\
\hline E18 & WG & 114.808 & 111 & 1.034 & 0.207 & 0.813 & $\mathrm{H}_{0}$ \\
\hline & Total & 115.237 & 113 & & & & \\
\hline & BG & 1.193 & 2 & 0.596 & & & \\
\hline E19 & WG & 97.167 & 111 & 0.875 & 0.681 & 0.508 & $\mathrm{H}_{0}$ \\
\hline & Total & 98.360 & 113 & & & & \\
\hline & BG & 10.014 & 2 & 5.007 & & & \\
\hline E20 & WG & 100.512 & 111 & 0.906 & 5.530 & 0.005 & $\mathbf{H}_{1}$ \\
\hline & Total & 110.526 & 113 & & & & \\
\hline E21 & BG & 4.935 & 2 & 2.467 & 2.222 & 0.113 & $\mathrm{H}_{0}$ \\
\hline
\end{tabular}


THE THE EFFECTS OF DELAYS IN ALGERIAN CONSTRUCTION PROJECTS: AN EMPIRICAL STUDY

\begin{tabular}{|c|c|c|c|c|c|c|c|}
\hline & WG & 123.249 & 111 & 1.110 & & & \\
\hline & Total & 128.184 & 113 & & & & \\
\hline & BG & 8.829 & 2 & 4.414 & & & \\
\hline E22 & WG & 113.425 & 111 & 1.022 & 4.320 & 0.016 & $\mathbf{H}_{1}$ \\
\hline & Total & 122.254 & 113 & & & & \\
\hline & BG & 1.166 & 2 & 0.583 & & & \\
\hline E23 & WG & 111.299 & 111 & 1.003 & 0.581 & 0.561 & $\mathrm{H}_{0}$ \\
\hline & Total & 112.465 & 113 & & & & \\
\hline & BG & 2.114 & 2 & 1.057 & & & \\
\hline E24 & WG & 137.325 & 111 & 1.237 & 0.854 & 0.428 & $\mathrm{H}_{0}$ \\
\hline & Total & 139.439 & 113 & & & & \\
\hline & BG & 1.318 & 2 & 0.659 & & & \\
\hline E25 & WG & 112.120 & 111 & 1.010 & 0.653 & 0.523 & $\mathrm{H}_{0}$ \\
\hline & Total & 113.439 & 113 & & & & \\
\hline & BG & 3.771 & 2 & 1.886 & & & \\
\hline E26 & WG & 188.650 & 111 & 1.700 & 1.109 & 0.333 & $\mathrm{H}_{0}$ \\
\hline & Total & 192.421 & 113 & & & & \\
\hline & BG & 2.078 & 2 & 1.039 & & & \\
\hline E27 & WG & 206.703 & 111 & 1.862 & 0.558 & 0.574 & $\mathrm{H}_{0}$ \\
\hline & Total & 208.781 & 113 & & & & \\
\hline & BG & 2.065 & 2 & 1.032 & & & \\
\hline E28 & WG & 111.900 & 111 & 1.008 & 1.024 & 0.362 & $\mathrm{H}_{0}$ \\
\hline & Total & 113.965 & 113 & & & & \\
\hline & BG & 3.071 & 2 & 1.536 & & & \\
\hline E29 & WG & 149.534 & 111 & 1.347 & 1.140 & 0.324 & $\mathrm{H}_{0}$ \\
\hline & Total & 152.605 & 113 & & & & \\
\hline & BG & 2.008 & 2 & 1.004 & & & \\
\hline E30 & WG & 115.115 & 111 & 1.037 & 0.968 & 0.383 & $\mathrm{H}_{0}$ \\
\hline & Total & 117.123 & 113 & & & & \\
\hline & BG & 2.715 & 2 & 1.357 & & & \\
\hline E31 & WG & 176.733 & 111 & 1.592 & 0.852 & 0.429 & $\mathrm{H}_{0}$ \\
\hline & Total & 179.447 & 113 & & & & \\
\hline
\end{tabular}

BW: Between Groups. WG: Within Groups

Table 8. Multiple comparisons Post-Hoc "LSD"

\begin{tabular}{|c|c|c|c|c|c|c|c|}
\hline \multirow[t]{2}{*}{ DV } & \multirow{2}{*}{$\begin{array}{l}\text { (I) } \\
\text { Org }\end{array}$} & \multirow{2}{*}{$\begin{array}{c}\mathrm{J}) \\
\text { Org }\end{array}$} & \multirow{2}{*}{$\begin{array}{l}\text { MD } \\
\text { (I-J) }\end{array}$} & \multirow[t]{2}{*}{ Std. Error } & \multirow[t]{2}{*}{ Sig. } & \multicolumn{2}{|c|}{$95 \% \mathrm{CI}$} \\
\hline & & & & & & $\begin{array}{l}\text { Lower } \\
\text { Bound }\end{array}$ & $\begin{array}{l}\text { Upper } \\
\text { Bound }\end{array}$ \\
\hline \multirow[t]{6}{*}{ E20 } & \multirow{2}{*}{ Ow } & Cns & $-0.531^{*}$ & 0.252 & 0.038 & -1.032 & -0.031 \\
\hline & & Cnt & $-0.823^{*}$ & 0.248 & 0.001 & -1.315 & -0.331 \\
\hline & \multirow{2}{*}{ Cns } & $\mathrm{Ow}$ & 0.531* & 0.252 & 0.038 & 0.031 & 1.032 \\
\hline & & Cnt & -0.292 & 0.198 & 0.143 & -0.683 & 0.100 \\
\hline & \multirow{2}{*}{ Cnt } & Ow & $0.823^{*}$ & 0.248 & 0.001 & 0.331 & 1.315 \\
\hline & & Cns & 0.292 & 0.198 & 0.143 & -0.100 & 0.683 \\
\hline
\end{tabular}




\begin{tabular}{|c|c|c|c|c|c|c|c|}
\hline E22 & \multirow{3}{*}{ Ow } & Cns & -0.353 & 0.268 & 0.191 & -0.884 & 0.178 \\
\cline { 3 - 8 } & & Cnt & $\mathbf{- 0 . 7 4 1}^{*}$ & 0.264 & 0.006 & -1.264 & -0.219 \\
\cline { 2 - 7 } & \multirow{3}{*}{ Cns } & Ow & 0.353 & 0.268 & 0.191 & -0.178 & 0.884 \\
\cline { 3 - 8 } & Cnt & -0.389 & 0.210 & 0.067 & -0.805 & 0.027 \\
\cline { 2 - 7 } & \multirow{2}{*}{ Cnt } & Ow & $\mathbf{0 . 7 4 1}$ & 0.264 & 0.006 & 0.219 & 1.264 \\
\cline { 3 - 8 } & Cns & 0.389 & 0.210 & 0.067 & -0.027 & 0.805 \\
\hline
\end{tabular}

DV: Dependent Variable. Org: Organism. MD: Mean Difference.CI: Confidence interval. Ow: Owners. Cns: Consultants. Cnt: Contractors

*. The mean difference is significant at the 0.05 level

\subsection{Factor analysis}

\subsubsection{Suitability of data}

Factor analysis technique was performed to sort out the effects of construction delay by grouping the variables that are highly correlated to each other and converting them into a single factor. However, before applying this technique suitability of data must be enquired. In this regard, the 'Kaiser-Meyer-Olkin Measure' of Sampling Adequacy (KMO), and 'Bartlett's Test of Sphericity' were conducted. 'Bartlett's measure' tests the null hypothesis that the original correlation matrix is an identity matrix (an identity matrix is a matrix in which all of the diagonal elements are 1 and all off-diagonal elements are 0 ). We want this test to be significant [13], in other words, we want to reject the null hypothesis. Moreover, the estimation of KMO speaks to the proportion of the squared connection between factors to the squared incomplete relationship between factors [10]. This measure varies between 0 and 1 , and value closes to 1 express that the correlations pattern is relatively dense and therefore factor analysis should give definite and strong outcomes Field, A 2013. [13].

As shown in Table 9, Bartlett's Test of Sphericity was significant at the level of 0.01 (with $\chi 2=1794.546$ and $p$-value $=0.00$ ) which indicates that the correlation matrix is not an identity matrix. As well, the KMO measure of sampling adequacy was sufficient with a value of 0.719 . From these results, we can say that the sample is adequate and the factor analysis can be applied.

Table 9. KMO and Bartlett's Test

KMO and Bartlett's Test

\begin{tabular}{|c|l|c|}
\hline \multicolumn{2}{|c|}{ KMO and Bartlett's Test } \\
\hline Kaiser-Meyer-Olkin Measure of Sampling Adequacy. & 0.719 \\
\hline \multirow{3}{*}{ Bartlett's Test of Sphericity } & Approx. Chi-Square & 1794.546 \\
\cline { 2 - 3 } & Df & 465 \\
\cline { 2 - 3 } & Sig. & 0.000 \\
\hline
\end{tabular}




\subsubsection{Rotation method and factors extracted}

The principal components method was employed with 'Varimax orthogonal rotation' in order to drive the minimum number of factors and explain the maximum portion of the variance in the original variable.

Using the latent root criterion (Eigenvalue greater than 1), nine (9) factors can be extracted. However, 'factors with less than three items are considered weak and unstable and they should be deleted' [47], as well items with a cross-loading should be removed. Consequently, factor analysis was iteratively repeated and items deleted sequentially yielding five (5) factors extracted from 19 final items, these factors explain $64.32 \%$ of the total variance. As given in Table 10, the 5 factors extracted were listed according to their variance explained as follows:

- Factor 1: 'bad public perception and losses of productivity, job, and income', this factor explains $18.053 \%$ of the total variance. Six items have been loading on this factor, negative public perception; loss of belief of citizens; social problem; litigation and claims; loss of productivity; loss of job and income' with loadings values of $0.890,0.875,0.741,0.555,0.491$, and 0.479 respectively.

The construction project is one of the most crucial sectors, given that it constitutes an efficient way to improve the standard of living [12, 40, 45], and contributes significantly to job and wealth creation, and socio-economic growth $[4,11,16$, $42,45]$. Delay in construction projects gives rise to waste of resources, which leads to disruption of work and then losses of productivity and losses of jobs and incomes $[10,16,22]$. Moreover delay often generates negative public perception and suspicion of corruption and inefficiency [16].

- Factor 2: 'wastage and quality problems' is the second group of effects with an eigenvalue of 2.118 ; this factor explains $12.312 \%$ of the total variance and consists of 'poor quality' with a loading value of 0.859 ; 'impact on the structure sustainability' ( $\mathrm{LV}=0.841)$; 'wastage and underutilisation of human and material resources' $(\mathrm{LV}=0.591)$; 'aging the project before its delivery' $(\mathrm{LV}=0.505)$. Delay causes waste of resources $[15,22,35,42]$ and has a significant impact on project quality $[15,26,27,41,42]$; in fact when project is delayed contractors seek to accelerate the work in order to avoid more time overrun and more extra cost accompanied with delay. Consequently poor quality will be the result that eventually affects sustainability [26]. On the other hand, delay causes late delivery of the project and when delay persists, it may age the project before its delivery and therefore the economic justification of the project may be lost [5].

- Factor 3: 'failure of the project and disruption of the program' explains $12.199 \%$ of the total variance, and it includes 3 attributes 'failure of the project', 'disruption of the program' and 'non-achievement of objectives' with loading values of $0.805,0.750$ and 0.738 respectively. Construction project deemed successful when it is finished on time, within budget, and to the quality requirements $[14,42]$. Delays in construction projects will conduct to failure in 
accomplishment project with the contract specifications and objectives, failure of the project, and disruption of the program.

- Factor 4: 'disruption of work and disputes' explains $11.589 \%$ of the total variance and it contains 3 components namely 'disruption of work' ( $L V=0.803$ ), 'disputes between the parties involved' $(\mathrm{LV}=0.698)$, and 'suspension of work' $(\mathrm{LV}=0.681)$. Delay gives rise to disruption of work, problems of communication, and disputes between project participants, which come down in assessing three aspects of delays; who was responsible for the delay, what is the extent of delay and so, what monetary awards should be made [2].

- Factor 5: named 'negative impact on the company'; the project delay has a negative impact on the company, 'to the contractor; delay means higher overhead costs because of the longer work period, higher material costs through inflation, and due to labour cost increases' [7]. This factor explains $10.164 \%$ of the total variance and it is constituted by three variables: 'penalty of delay on the company' ( $\mathrm{LV}=0.793$ ); 'failure of the company' ( $\mathrm{LV}=0.772)$; 'reducing the corporate profit margin of contractors $(\mathrm{LV}=0.671)$.

Table 10. Rotated Component Matrix and variance explained

\begin{tabular}{|l|c|c|c|c|c|}
\hline \multirow{2}{*}{} & \multicolumn{5}{|c|}{ Component } \\
\cline { 2 - 6 } & 1 & 2 & 3 & 4 & 5 \\
\hline E17 & 0.890 & & & & \\
\hline E15 & 0.875 & & & & \\
\hline E20 & 0.741 & & & & \\
\hline E22 & 0.555 & & & & \\
\hline E23 & 0.491 & & & & \\
\hline E8 & 0.479 & & & & \\
\hline E9 & & 0.859 & & & \\
\hline E10 & & 0.841 & & & \\
\hline E5 & & 0.591 & & & \\
\hline E29 & & 0.505 & & & \\
\hline E28 & & & 0.805 & & \\
\hline E30 & & & 0.750 & & \\
\hline E25 & & & 0.738 & & \\
\hline E21 & & & & 0.803 & \\
\hline E24 & & & & 0.698 & \\
\hline E13 & & & & 0.681 & \\
\hline E12 & & & & & 0.793 \\
\hline E11 & & & & & 0.772 \\
\hline Eigenvalue & & & & & 0.671 \\
\hline Variance explained (\%) & 18.053 & 12.312 & 12.199 & 11.589 & 10.164 \\
\hline Cumulative \% & 18.053 & 30.364 & 42.563 & 54.152 & 64.316 \\
\hline
\end{tabular}


Extraction Method: Principal Component Analysis. Rotation Method: Varimax with Kaiser Normalization. Rotation converged in 16 iterations.

\subsection{Relationship between the five (5) groups of effects}

As mentioned in the introduction section a primary contribution of this study to the existing literature is to categorise the identified effects into main groups and to measure the causality relationship among these groups. The grouping of the effects has been done (using factor analysis) and 5 factors have been extracted. To test the relationship among these factors (groups of effects) we propose the following hypotheses:

Table 11. Hypotheses for testing the relationship between groups of effects

\begin{tabular}{|c|c|c|}
\hline H1 & $\begin{array}{l}\text { Factor } 2 \\
\rightarrow \text { Factor } 1\end{array}$ & $\begin{array}{l}\text { 'wastage and quality problems' impact 'bad public perception } \\
\text { and losses of productivity, job, and income' }\end{array}$ \\
\hline $\mathrm{H} 2$ & $\begin{array}{l}\text { Factor } 2 \\
\rightarrow \text { Factor } 3\end{array}$ & $\begin{array}{l}\text { 'wastage and quality problems' impact: 'failure of the project } \\
\text { and disruption of the program' }\end{array}$ \\
\hline H3 & $\begin{array}{l}\text { Factor } 2 \\
\rightarrow \text { Factor } 5\end{array}$ & $\begin{array}{l}\text { 'wastage and quality problems' impact 'negative impact on } \\
\text { the company' }\end{array}$ \\
\hline $\mathrm{H} 4$ & $\begin{array}{l}\text { Factor } 3 \\
\rightarrow \text { Factor } 1\end{array}$ & $\begin{array}{l}\text { 'failure of the project and disruption of the program' impact } \\
\text { 'bad public perception and losses of productivity, job, and } \\
\text { income' }\end{array}$ \\
\hline H5 & $\begin{array}{l}\text { Factor } 3 \\
\rightarrow \text { Factor } 5\end{array}$ & $\begin{array}{l}\text { 'failure of the project and disruption of the program' impact } \\
\text { 'negative impact on the company' }\end{array}$ \\
\hline H6 & $\begin{array}{l}\text { Factor } 4 \\
\rightarrow \text { Factor } 1\end{array}$ & $\begin{array}{l}\text { 'disruption of work and disputes' impact 'bad public } \\
\text { perception and losses of productivity, job, and income' }\end{array}$ \\
\hline H7 & $\begin{array}{l}\text { Factor } 4 \\
\rightarrow \text { Factor } 2\end{array}$ & $\begin{array}{l}\text { 'disruption of work and disputes' impact 'wastage and quality } \\
\text { problems' }\end{array}$ \\
\hline H8 & $\begin{array}{l}\text { Factor } 4 \\
\rightarrow \text { Factor } 3\end{array}$ & $\begin{array}{l}\text { 'disruption of work and disputes' impact 'failure of the project } \\
\text { and disruption of the program' }\end{array}$ \\
\hline H9 & $\begin{array}{l}\text { Factor } 4 \\
\rightarrow \text { Factor } 5\end{array}$ & $\begin{array}{l}\text { 'disruption of work and disputes' impact 'negative impact on } \\
\text { the company' }\end{array}$ \\
\hline H10 & $\begin{array}{l}\text { Factor } 5 \\
\rightarrow \text { Factor } 1\end{array}$ & $\begin{array}{l}\text { 'negative impact on the company' impact 'bad public } \\
\text { perception and losses of productivity, job, and income' }\end{array}$ \\
\hline
\end{tabular}

The Smart PLS method was selected to test these hypotheses, and to propose a structural model that describes the relationship among the 5 factors. This method is well-known method for estimating path coefficients in structural models and it has been used in numerous research studies [18]. However before applied this method, we should assess the measurement model to ensure the reliability and validity of each construct's factor.

\subsubsection{Measures}

First, we start by evaluating the measurement model to ensure that each factors' construct is reliable and valid. 


\subsubsection{Internal consistency reliability}

The internal reliability of the measurement model was measured using 'Cronbach's Alpha', 'Composite Reliability (CR)'and 'Dijkstra Henseler's RhoA'. As shown in Table 12, the results were as follows: the Cronbach's Alpha that measures internal consistency reliability ranged from 0.662 to 0.840 and represent a good consistency. The Composite Reliability that depicts the degree to which the construct indicators indicate the latent construct the values of the Composite reliability ranged from 0.801 to 0.882 and exceed the recommended value of 0.6 [18]. The Rho-A also exceed minimum threshold and it ranged from 0.740 to 0.849 , this indicator lies between the upper bound (CR) and the lower bound $(\mathrm{Ca})$ for internal consistency reliability and serve as a good representation of a construct's internal reliability [18].

Thus, all the values exceed the minimum threshold value of 0.6 [18] for all variables indicating that the measurement model has a good consistency and reliability.

\subsubsection{Convergent validity}

The convergent validity of the measurement model was assessed through 'Average Variance Extracted (AVE)'. The Average Variance Extracted (AVE) reflects the total amount of variance in the indicators accounted for by the latent construct. As shown in Table 12, the AVE values found higher than 0.5 which indicate that the latent variables for our model composition are valid, in consensus with [18].

Table 12. Construct reliability and validity

\begin{tabular}{|l|c|c|c|c|}
\hline & $\begin{array}{c}\text { Cronbach's } \\
\text { Alpha }\end{array}$ & rho_A & $\begin{array}{c}\text { Composite } \\
\text { Reliability }\end{array}$ & $\begin{array}{c}\text { Average Variance } \\
\text { Extracted (AVE) }\end{array}$ \\
\hline Factor 1 & 0.840 & 0.849 & 0.882 & 0.557 \\
\hline Factor 2 & 0.726 & 0.740 & 0.823 & 0.538 \\
\hline Factor 3 & 0.765 & 0.789 & 0.862 & 0.676 \\
\hline Factor 4 & 0.751 & 0.752 & 0.858 & 0.668 \\
\hline Factor 5 & 0.662 & 0.803 & 0.801 & 0.577 \\
\hline
\end{tabular}

\subsubsection{Discriminant validity}

The discriminant validity is the extent to which a construct is empirically distinct from other constructs in the structural model [18]. 'Fornell and Lacker criterion' was used in order to assess the discriminant validity of the measurement model. The highest correlation ( 0.822 ) was found between 'Factor $3 \rightarrow$ Factor 3' while the lowest $(0.180)$ correlation was found between 'Factor $3 \rightarrow$ Factor 5 '. In order to optimize the assessment of discriminant validity in variance-based structural equation modelling, we used the new criterion of Heterotrait-Monotrait ratio (HTMT) proposed by [21], which is considered superior to Fornell-Larcker indicator $[18,20]$. As depicted in Table 13, all the values of HTMT were 
significantly lower than the threshold value of 0.90 , thus the model assessments prove a good evidence of validity and reliability.

Table 14. Fornell-Lacker Criterion and HTMT Ratio

\begin{tabular}{|c|c|c|c|c|c|c|c|c|c|c|}
\hline & \multicolumn{4}{|c|}{ Fornell-Lacker Criterion } & \multicolumn{4}{|c|}{ Heterotrait-Monotrait Ratio (HTMT) } \\
\cline { 2 - 12 } & F1 & F2 & F3 & F4 & F5 & F1 & F2 & F3 & F4 & F5 \\
\hline F1 & 0.746 & & & & & & & & & \\
\hline F2 & 0.391 & 0.734 & & & & 0.471 & & & & 0.471 \\
\hline F3 & 0.393 & 0.300 & 0.822 & & & 0.453 & 0.342 & & & 0.453 \\
\hline F4 & 0.542 & 0.253 & 0.469 & 0.817 & & 0.669 & 0.326 & 0.606 & & 0.669 \\
\hline F5 & 0.389 & 0.335 & 0.180 & 0.192 & 0.759 & 0.441 & 0.403 & 0.284 & 0.258 & 0.441 \\
\hline
\end{tabular}

F: Factor

\subsubsection{Structural model}

Structural model coefficients for the relationships between the constructs are derived from estimating a series of regression equations [18]. Before assessing the structural relationships, collinearity must be tested to make sure it does not bias the regression results [18]. The results show that the values of the inflation factor (VIF) variance ranged from 1.00 to 1.344 which is lower than 3 , thus it considered ideally in consensus with Hair et al. [18] and no issue of collinearity is present with our factors(Table 15).

Table 15. Collinearity statisctics (VIF)

\begin{tabular}{|l|l|l|l|l|l|}
\hline & Factor 1 & Factor 2 & Factor 3 & Factor 4 & Factor 5 \\
\hline Factor 1 & & & & & \\
\hline Factor 2 & 1.219 & & 1.068 & & 1.119 \\
\hline Factor 3 & 1.344 & & & & 1.342 \\
\hline Factor 4 & 1.315 & 1.000 & 1.068 & & 1.305 \\
\hline Factor 5 & 1.144 & & & & \\
\hline
\end{tabular}

After cheeking and proving that there is no collinearity issue with our factors, we start the assessment of the structural model with by examining the coefficient of determination $\left(\mathrm{R}^{2}\right)$, the effect size $\left(\mathrm{f}^{2}\right)$, and the $\mathrm{p}$-value corresponding to the $\mathrm{t}$-test.

\subsubsection{The coefficient of determination $\left(R^{2}\right)$}

According to Hair et al. [18], the $\mathrm{R}^{2}$ of $0.75,0.50$, and 0.25 can be considered substantial, moderate, and weak. Figure 6 shows that the $\mathrm{R}^{2}$ ranged from 0.064 to 0.421 (moderate to weak). The high value of $\mathrm{R}^{2}$ corresponding to the 'Factor 1 ' which indicate that $42.1 \%$ of the variance in 'Factor 1 ' is explained by 'Factor 2, 'Factor 3' and 'Factor 4'. While, 25.5\% of the variance in 'Factor 3' is explained by 'Factor 2' and 'Factor 4'. However, 'Factor 4' explains $12.6 \%$ of the variance in 'Factor 5'. And the 'Factor 1' and 'Factor 3' jointly explain only $0.64 \%$ of the variance in 'Factor 2'. 


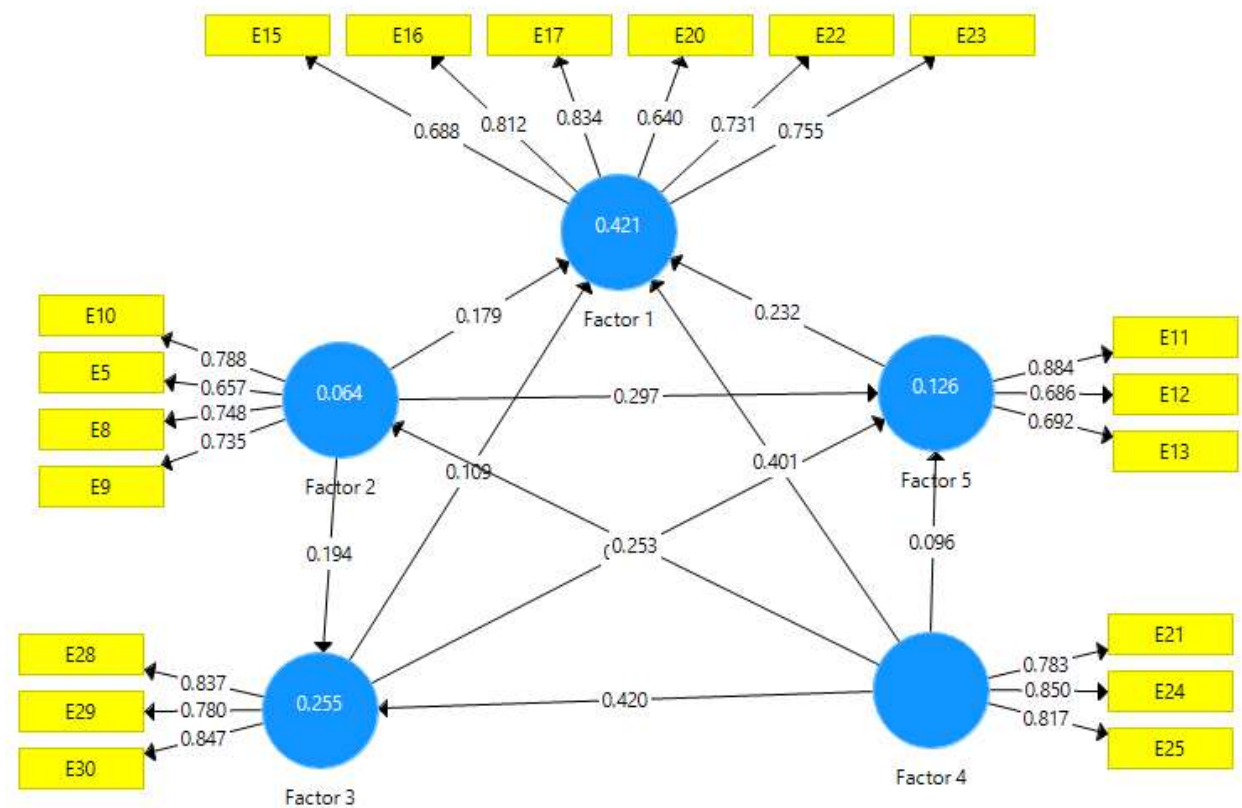

Fig. 6. The Path Coefficients of the structural model

\subsubsection{The effects size $\left(f^{2}\right)$}

From the rule of thumb small, medium and large effect sizes are represented by values greater than $0.02,0.15$, and 0.35 , respectively [18]. The resulting effect size value of each factor in the model ranges from 0.002 to 0.221 , which are included in the category of small to medium.

The path coefficient provide significant values (at significance level of 5\%) for most relationships, only three (3) relationships were found not significant: 'Factor $3 \rightarrow$ Factor 1'; 'Factor $3 \rightarrow$ Factor 5'; 'Factor $4 \rightarrow$ Factor 5'. Thus, the following hypotheses were rejected $\mathrm{H} 4, \mathrm{H} 5$, and $\mathrm{H} 9$. However, the other 7 hypotheses were supported $\mathrm{H} 1, \mathrm{H} 2, \mathrm{H} 3, \mathrm{H} 6, \mathrm{H} 7, \mathrm{H} 8$, and $\mathrm{H} 10$.

The Factor 2'wastage and quality problems' positively and significantly affect the 'bad public perception and losses of productivity, job and incomes', 'Failure of project and disruption of program' and 'negative impact on the company' with a path coefficient of $0.179 ; 0.194$ and 0.297 , however its impact is small (the $\mathrm{f}^{2}$ was respectively $0.046,0.047$ and 0.090 ).

The Factor 4 'disruption of work and disputes' has a medium positive and significant impact on 'bad public perception and loses of productivity, job and incomes' and 'failure of project and disruption of the program' with a path coefficient of 0.401 and 0.420 respectively, and it has a small positive and significant impact on 'project failure and disruption of the program' with a path 
coefficient of 0.253. Also, the 'negative impact on the company (Factor 5)' influence significantly and positively the 'bad public perception and losses of productivity, job and incomes (Factor 1)'.

Table 16. Path coefficients

\begin{tabular}{|l|c|c|c|c|c|c|c|}
\hline \multicolumn{1}{|c|}{ Relations } & $\mathrm{O}$ & $\mathrm{M}$ & $\mathrm{SD}$ & $\mathrm{T}$ & $f^{2}$ & $\begin{array}{c}\mathrm{P}- \\
\text { values }\end{array}$ & Conclusion \\
\hline $\begin{array}{l}\text { Factor 2 } \\
\rightarrow \text { Factor } 1\end{array}$ & 0.179 & 0.180 & 0.089 & 2.004 & 0.046 & 0.046 & Supported \\
\hline $\begin{array}{l}\text { Factor 2 } \\
\rightarrow \text { Factor 3 }\end{array}$ & 0.194 & 0.202 & 0.086 & 2.253 & 0.047 & 0.025 & Supported \\
\hline $\begin{array}{l}\text { Factor 2 } \\
\rightarrow \text { Factor 5 }\end{array}$ & 0.297 & 0.308 & 0.097 & 3.068 & 0.090 & 0.002 & Supported \\
\hline $\begin{array}{l}\text { Factor 3 } \\
\rightarrow \text { Factor 1 }\end{array}$ & 0.109 & 0.104 & 0.102 & 1.073 & 0.015 & 0.284 & $\begin{array}{c}\text { Not } \\
\text { supported }\end{array}$ \\
\hline $\begin{array}{l}\text { Factor 3 } \\
\rightarrow \text { Factor 5 }\end{array}$ & 0.046 & 0.041 & 0.127 & 0.362 & 0.002 & 0.717 & $\begin{array}{c}\text { Not } \\
\text { supported }\end{array}$ \\
\hline $\begin{array}{l}\text { Factor 4 } \\
\rightarrow \text { Factor 1 }\end{array}$ & 0.401 & 0.411 & 0.100 & 4.011 & 0.211 & 0.000 & Supported \\
\hline $\begin{array}{l}\text { Factor 4 } \\
\rightarrow \text { Factor 2 }\end{array}$ & 0.253 & 0.267 & 0.096 & 2.644 & 0.068 & 0.008 & Supported \\
\hline $\begin{array}{l}\text { Factor 4 } \\
\rightarrow \text { Factor 3 }\end{array}$ & 0.420 & 0.421 & 0.105 & 4.011 & 0.221 & 0.000 & Supported \\
\hline $\begin{array}{l}\text { Factor 4 } \\
\rightarrow \text { Factor 5 }\end{array}$ & 0.096 & 0.104 & 0.100 & 0.963 & 0.008 & 0.336 & $\begin{array}{c}\text { Not } \\
\text { supported }\end{array}$ \\
\hline $\begin{array}{l}\text { Factor 5 } \\
\rightarrow \text { Factor 1 }\end{array}$ & 0.232 & 0.235 & 0.086 & 2.701 & 0.081 & 0.007 & Supported \\
\hline OFrgat Smple
\end{tabular}

O: Original Sample, M: Sample Mean, SD: Standard Deviation, T: |O/STDEV|, CI:

Confidence interval, S: Supported, NS: Not Supported

\subsection{Comparison with other countries}

This part is designed to get an overview of the effects of construction delay throughout the world. A comparison of the top effects of delay in Algeria with 12 countries ( 22 previous studies) has been done. The results show that time overrun' is not only the most encountered effect of delays in Algerian construction projects but also, it appears in 20 other studies with an occurrence percentage of $95 \%$ (this effect was ranked first in 14 studies and the $2^{\text {nd }}$ in 7 studies). Also, 'cost overrun' is one of the most popular and frequent effect of delay and it's similarly yielded an occurrence of $95 \%$. This effect was ranked first in the studies of $[6,17$, $19,23,25,42]$, the $2^{\text {nd }}$ in 13 studies, and the $3^{\text {rd }}$ in our study and in the study of [16]. It was followed by 'disputes' and 'total abandonment' which were ranked $2^{\text {nd }}$ in 10 studies representing an occurrence of $45 \%$; these disputes can lead to litigation and arbitration if they are not solved timeously. That is explained the 
following effects 'litigation' and 'arbitration' which ranked the $3^{\text {rd }}$ and $4^{\text {th }}$ respectively at $41 \%$ and $36 \%$ (these effects do not appear as major effects of delay in Algeria). However, 'Bad quality' was rated $5^{\text {th }}$ with an occurrence of $27 \%$, followed by 'wastage of scarce resources' and 'claims' which were appeared in 5 studies representing an occurrence percentage of $23 \%$. The $7^{\text {th }}$ effect was 'loss of profit' with an occurrence of $18 \%$. Further, 'failure of the project', 'negative social impact' and 'termination of contract' were similarly ranked $8^{\text {th }}$ with an occurrence percentage of $9 \%$. Succeeded by 'negative impact on the economy of country'; which was ranked last at 5\%. This effect was found to be specific for Algeria. From all these forgoing, we can notice that time and cost overruns were the top famous effects of delay worldwide; and that many countries shared the same effects of delay even though they are not in the same region. Table17 summarizes the results of the comparison, and Figure 7 presents the percentage of occurrence of the top effects of delays worldwide.

Table17. Comparison of the top effects of delays worldwide

\begin{tabular}{|c|c|c|c|c|c|c|c|c|c|c|c|c|c|c|}
\hline & & & & & to & effe & cts & $\mathrm{de}$ & ay w & orldy & ide & & & \\
\hline $\begin{array}{l}\text { Country of the } \\
\text { study }\end{array}$ & 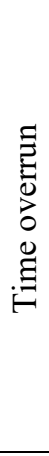 & 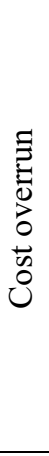 & 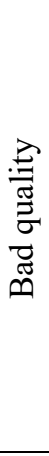 & 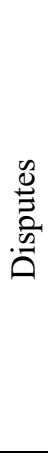 & $\frac{\mathscr{\Xi}}{\Xi}$ & 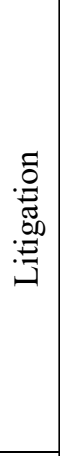 & 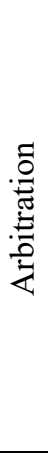 & 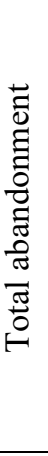 & 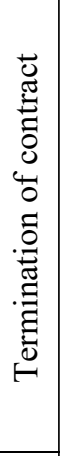 & 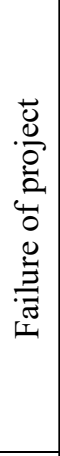 & 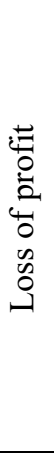 & 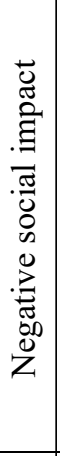 & 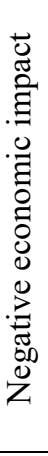 & 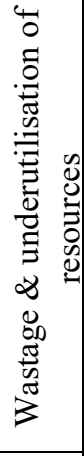 \\
\hline $\begin{array}{l}\text { Algeria (our } \\
\text { study) }\end{array}$ & 1 & 1 & 1 & 0 & 0 & 0 & 0 & 0 & 0 & 1 & 0 & 0 & 1 & 1 \\
\hline Nigeria[31] & 1 & 1 & 0 & 0 & 0 & 0 & 0 & 0 & 0 & 0 & 0 & 0 & 0 & 0 \\
\hline Nigeria[33] & 1 & 1 & 0 & 0 & 1 & 0 & 0 & 0 & 0 & 0 & 0 & 0 & 0 & 0 \\
\hline Nigeria[35] & 1 & 1 & 0 & 1 & 0 & 1 & 1 & 1 & 0 & 0 & 1 & 0 & 0 & 1 \\
\hline Nigeria[41] & 1 & 1 & 1 & 1 & 1 & 0 & 0 & 1 & 0 & 0 & 0 & 1 & 0 & 0 \\
\hline Nigeria[3] & 1 & 1 & 0 & 1 & 0 & 1 & 1 & 1 & 0 & 0 & 0 & 0 & 0 & 0 \\
\hline Tanzania[24] & 1 & 1 & 0 & 1 & 0 & 0 & 0 & 0 & 0 & 0 & 0 & 1 & 0 & 1 \\
\hline Ghana[6] & 1 & 1 & 0 & 0 & 0 & 1 & 1 & 0 & 0 & 0 & 0 & 0 & 0 & 0 \\
\hline Zimbabwe[30] & 1 & 1 & 0 & 0 & 0 & 0 & 0 & 0 & 0 & 0 & 0 & 0 & 0 & 0 \\
\hline Libya[25] & 1 & 1 & 0 & 1 & 0 & 0 & 1 & 1 & 0 & 0 & 0 & 0 & 0 & 0 \\
\hline Sudan[23] & 1 & 1 & 0 & 0 & 0 & 0 & 0 & 0 & 0 & 0 & 0 & 0 & 0 & 0 \\
\hline
\end{tabular}



PROJECTS: AN EMPIRICAL STUDY

\begin{tabular}{|l|c|c|c|c|c|c|c|c|c|c|c|c|c|c|} 
South Africa[34] & 0 & 0 & 1 & 0 & 0 & 0 & 0 & 0 & 0 & 0 & 0 & 0 & 0 & 0 \\
\hline South Africa[27] & 1 & 1 & 1 & 1 & 1 & 0 & 0 & 0 & 0 & 0 & 1 & 0 & 0 & 0 \\
\hline $\begin{array}{l}\text { Sub Saharan- } \\
\text { Africa[16] }\end{array}$ & 1 & 1 & 0 & 1 & 1 & 1 & 0 & 1 & 0 & 1 & 0 & 0 & 0 & 1 \\
\hline Ethiopia[42] & 1 & 1 & 1 & 0 & 0 & 0 & 0 & 1 & 0 & 0 & 0 & 0 & 0 & 1 \\
\hline Ethiopia[17] & 1 & 1 & 0 & 0 & 0 & 1 & 1 & 0 & 1 & 0 & 0 & 0 & 0 & 0 \\
\hline Somalia[38] & 1 & 1 & 0 & 1 & 0 & 0 & 0 & 0 & 0 & 0 & 1 & 0 & 0 & 0 \\
\hline Malaysia[45] & 1 & 1 & 1 & 1 & 1 & 1 & 1 & 1 & 1 & 0 & 1 & 0 & 0 & 0 \\
\hline Malaysia[1] & 1 & 1 & 0 & 0 & 0 & 0 & 1 & 0 & 0 & 0 & 0 & 0 & 0 & 0 \\
\hline Malaysia[39] & 1 & 1 & 0 & 1 & 0 & 1 & 1 & 1 & 0 & 0 & 0 & 0 & 0 & 0 \\
\hline Pakistan[37] & 1 & 1 & 0 & 0 & 0 & 1 & 0 & 1 & 0 & 0 & 0 & 0 & 0 & 0 \\
\hline Pakistan[19] & 1 & 1 & 0 & 0 & 0 & 1 & 0 & 1 & 0 & 0 & 0 & 0 & 0 & 0 \\
\hline $\begin{array}{l}\text { Frequency of } \\
\text { occurrence }\end{array}$ & 21 & 21 & 6 & 10 & 5 & 9 & 8 & 10 & 2 & 2 & 4 & 2 & 1 & 5 \\
\hline
\end{tabular}

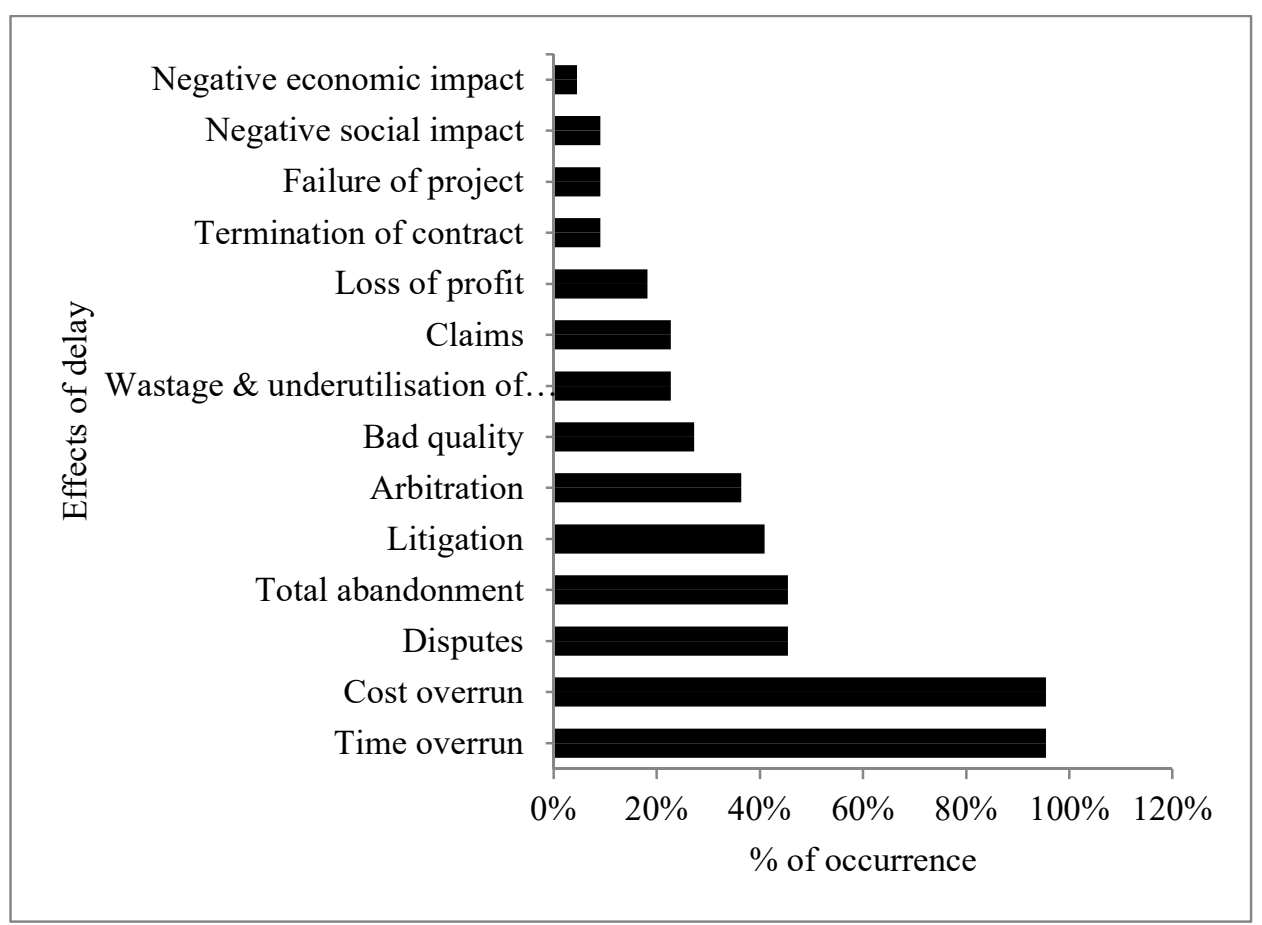

Fig. 7.The percentage of occurrence of the top effects of delays worldwide 


\section{CONCLUSION}

The present study is designed to make a comprehensive list of the effects of delay and to assess the perceptions of the key project stakeholders regarding the relative importance of these effects in the Algerian construction projects.

31 effects of delay have been identified, and then the relative importance of these effects has been measured using the relative importance index (RII). The findings show that time overrun; non-achievement of objectives; cost overrun; poor quality; failure of the project; negative impact on the economy of the country; negative impact on the image of the city; loss of productivity; wastage and underutilisation of human and material resources; disruption of the program were the top 10 effects of delay in Algeria. Moreover, one-way ANOVA was adopted to measure the degree of agreement between the perceptions of the major stakeholders. The results reveal that there is relatively a good agreement in their assessments of the relative importance of 29 effects.

A primary contribution of this study to the existing literature is to categorise the identified effects into main groups and to measure the relationship among these groups. The factor analysis technique was performed categorized the identified effects into main groups, and it yielded 5 groups (factors) namely: 'bad public perception and losses of productivity, job, and income', 'wastage and quality problems', 'failure of the project and disruption of the program', 'disruption of work and disputes', and 'negative impact on the company'. After that, the relationship between these groups was tested using the SMART-PLS, and a structural model has been developed. The findings allow us to confirm the existence of 7 relationships out of 10 proposed.

At the end, a comparison of the 10 most important effects of delay in Algeria with 11 countries was done; the findings show that time and cost overruns were the most common effects of delay worldwide, and that many countries shared the same effects of delay even though they are not in the same region.

The current study provides significant insights to practitioners in construction projects and helps them to choose the correct actions to deal with delays and to reduce its effects once they happen.

\section{REFERENCES}

1. Abdullah, MR, Abdul Azis, AA and Abdul Rahman, I 2009. Potential Effects on Large Mara Construction Projects Due To Construction Delay. International Journal of Integrated Engineering (IJIE)1, 53-62.

2. Ahmed, SM, Azhar, S, Castillo, M and Kappagantula, P 2002. Construction Delays in Florida: An Empirical Study. Final Report. Florida International University:, no. August. Dept. of Community Affairs, Miami. 
3. Aibinu, AA and Jagboro, GO 2002. The Effects of Construction Delays on Project Delivery in Nigerian Construction Industry. International Journal of Project Management 20, 593-99.

4. Alagidede, $\mathrm{P}$ and Jones $\mathrm{O}, \mathrm{M}$ 2018. Construction, Institutions and Economic Growth in Sub-Saharan Africa. ERSA Working Pape 10, 136-63.

5. Alavifar, $\mathrm{AH}$ and Shadab $\mathrm{M}$ 2014. Identification, Evaluation and Classification of Time Delay Risks of Construction Project in Iran. International Conference on Industrial Proceedings of the 2014 International Conference on Industrial Engineering and Operations Management Bali, Indonesia, January 7 - 9, 219-229.

6. Amoatey, CT, Yaa AA, Ebenezer, A and Samuel, F 2015. Analysing Delay Causes and Effects in Ghanaian State Housing Construction Projects. International Journal of Managing Projects in Business 8, 198-214.

7. Assaf, SA and Al-Hejji, S 2006. Causes of Delay in Large Construction Projects. International Journal of Project Management 24, 349-57.

8. Bajjou, MS and Chafi, A 2020. Empirical Study of Schedule Delay in Moroccan Construction Projects. International Journal of Construction Management 20, 783-800.

9. Chiang, YH, Li, T and Francis KWW 2015. Causal Relationship between Construction Activities, Employment and GDP: The Case of Hong Kong. Habitat International 46, 1-12.

10. Dixit, S, Pandey, AK, Mandal, SN and Bansal, S 2017. A Study of Enabling Factors Affecting Construction Productivity: Indian Scnerio. International Journal of Civil Engineering \& Technology 8, 741-58.

11. Dlamini, M and Cumberlege, R 2021. The Impact of Cost Overruns and Delays in the Construction Business. IOP Conference Series: Earth and Environmental Science 654, 012029.

12. Durdyev, S, Maksat, O and Syuhaida, I 2017. Causes of Delay in Residential Construction Projects in Cambodia. Cogent Engineering 4, 1-12.

13. Ojoko, EO, Tanko, BL, Ojoko, O and Enegbuma,WL 2016. Project Delay Causes And Effects In The Construction Construction Industry. IGCESH2016, University of Technology Malaysia, Johor Bahru, Malaysia, August, 15-17, 1-12.

14. Field, A 2013. Discovering Statistics Using IBM SPSS Statistics. London. (UK): Publisher. SAGE Publications Ltd. 4th ed.

15. Frimpong, Y, Oluwoye, J and Crawford, L 2003. Causes of Delay and Cost Overruns in Construction of Groundwater Projects in a Developing Countries; Ghana as a Case Study. International Journal of Project Management 21, 321-26.

16. Gashahun, AD 2020. Causes and Effects of Delay on African Construction Projects: A State of the Art Review. Civil and Environmental Research 12, 
41-53.

17. Gbahabo, PT and Ajuwon, OS 2017. Effects of Project Cost Overruns and Schedule Delays in Sub-Saharan Africa. European Journal of Interdisciplinary Studies 7, 46.

18. Gebrehiwet, $\mathrm{T}$ and Luo, H 2017. Analysis of Delay Impact on Construction Project Based on RII and Correlation Coefficient: Empirical Study. Procedia Engineering 196, 366-74.

19. Hair, JF, Jeffrey, JR, Marko, S and Christian, MR 2018. Article Information: When to Use and How to Report the Results of PLS-SEM. European Business Review 31, 2-24.

20. Haq, S, Rahsid, Y and Aslam, MS 2014. Causes of Delay in Construction Projects of Punjab-Pakistan: An Empirical Study." Journal of Basic and Applied Scientific Research 4, 98-104.

21. Henseler, J 2018. Partial Least Squares Path Modeling: Quo Vadis? Quality and Quantity 52, 1-8.

22. Henseler, J, Christian, MR and Marko, S 2015. A New Criterion for Assessing Discriminant Validity in Variance-Based Structural Equation Modeling. Journal of the Academy of Marketing Science 43, 115-35.

23. Kamalan, H, 2020. Root Cause Analysis of Delays in Dam Construction (Case Studies : Karun-3, Marun, Shafaroud and Jamishan Dams) Journal of Hydraulic Structures 6, 45-58.

24. Khair, K, Hazir, F, Zainai, M and Mohammad, R 2016. Causes and Effects of Delay Factors in Road Construction Projects in Sudan. International Journal of Applied Engineering Research 11, 9526-33.

25. Kikwasi, G 2012. Causes and Effects of Delays and Disruptions in Construction Projects in Tanzania. Australasian Journal of Construction Economics and Building - Conference Series 1, 52-59.

26. Kuşakc1, AO, Berk, A and Emir, B 2017. An Analysis of Causes and Effects of Delays in Construction Projects in Libyan Oil Industry. Karaelmas Fen ve Mühendislik Dergisi 7, 274-82.

27. Mahamid, I 2017. Schedule Delay in Saudi Arabia Road Construction Projects: Size, Estimate, Determinants and Effects. International Journal of Architecture, Engineering and Construction 6, 51-58

28. Mukuka, M, Aigbavboa, C and Thwala,W 2015. Effects of Construction Projects Schedule Overruns: A Case of the Gauteng Province, South Africa. Procedia Manufacturing 3, 1690-95.

29. Ngacho, C and Das, D 2014. A Performance Evaluation Framework of Development Projects: An Empirical Study of Constituency Development Fund (CDF) Construction Projects in Kenya. International Journal of Project Management 32, 492-507.

30. Niazai, GA and Gidado, K 2012. Causes of Project Delay in the Construction 
Industry in Afghanistan. Proceedings of EPPM 2012 International Conference on Engineering, Project and Production Management. United Kingdom University of Brighton, September, 10-11, 63-74

31. Nyoni, T 2018. An Empirical Assessment of Causes \& Effects of Delay in Residential Construction Projects In. International Journal of Advances in Engineering \& Scientifc Research 5, 34-46.

32. Obodoh, D 2016. Causes and Effects of Construction Project Delays in Nigerian Construction Industry. International Journal of Innovative Science, Engineering \& Technology 3, 65-84.

33. Oladinrin, TO, Ogunsemi, DR and Aje, IO 2012. Role of Construction Sector in Economic Growth: Empirical Evidence from Nigeria. FUTY Journal of the Environment 7, 50-60.

34. Oshungade, OO and Kruger, D 2017. A Comparative Study of Causes and Effects of Project Delays and Disruptions in Construction Projects in the South African Construction Industry. Journal of Construction Engineering and Project Management 7, 13-25.

35. Owalabi, JD et al. 2014. Causes and Effects of Delay on Project Construction Delivery Time. International Journal of Education and Research 2, 197208.

36. Rachid, Z, Boudouh, T and Baheddi, M 2019. Causes of Schedule Delays in Construction Projects in Algeria. International Journal of Construction Management 19, 371-81.

37. Rashid, Y 2020. Analysis of Delay Factors and Their Effects on Construction Projects. Management Science Letters 10, 1197-1204.

38. Salah, A and Ahmed, M 2018. Causes and Effect of Delay on Construction Project Delivery Time in Somalia : Hanad Construction \& General Trading Company Case Study .

39. Sambasivan, M and Soon, YW 2007. Causes and Effects of Delays in Malaysian Construction Industry. International Journal of Project Management 25, 517-26.

40. Santos, J and Reynaldo, A 1999. Cronbach's Alpha: A Tool for Assessing the Reliability of Scales. Journal of Extension 37, 1-5.

41. Sunjka, BP and Jacob, U 2013. Significant causes and effects of project delays in the Niger delta region, Nigeria. SAIIE25 Proceedings, Stellenbosch, South Africa, July, 9th - 11th, 1-14

42. Serani, N, Dusso, T and Wodaje, B 2020. The Causes and Effects of Delay of Building Construction in Ethiopia, Southern Nation Nationalities of People Region in Gurage Zone (Case of Wolkite Town). Civil and Environmental Research 12, 12-21.

43. Sweis, G, Sweis, R, Abu Hammad, A and Shboul, A 2008. Delays in Construction Projects: The Case of Jordan. International Journal of Project 
Management 26 (6): 665-74.

44. Tafazzoli, M and Shrestha, PP 2017. Investigating Causes of Delay in U.S. Construction Projects, 53rd ASC Annual International Conference Proceedings, Associated Schools of Construction, April 5-8, 611-21.

45. Ullah, K, Khan, MS, Lakhiar, MT, Vighio, AA and Sohu, S 2018. Ranking of Effects of Construction Delay: Evidence from Malaysian Building Projects. Journal of Applied Engineering Sciences 8, 79-84.

46. Yogita, G and Attarde, P 2015. Assessment Of Significant Causes And Effects Of Delays On The Projects Completion Period. InternInternational Journal of Modern Trends in Engineering and Research 02, 88-93 .

47. Costello, AB and Osborne, J (2005). Best practices in exploratory factor analysis: four recommendations for getting the most from your analysis, Practical Assessment, Research, and Evaluation 10, 1-9.

Editor received the manuscript: 31.01.2021 